\title{
Lectotype designation and redescription of four commonly collected Neotropical species of Strumigenys (Hymenoptera: Formicidae)
}

\author{
Thiago Sanches Ranzani Da SILVA ${ }^{\circledR 1, *}$, Júlio Cezar Mário CHAUL ${ }^{\circledR} 2$ \& \\ Rodrigo Machado FEITOSA ${ }^{\circledR 3}$ \\ 1,3 Departamento de Zoologia, Universidade Federal do Paraná, \\ Av. Cel. Francisco Heráclito dos Santos, 100, P.O. Box 19020, Curitiba, PR, Brazil. \\ ${ }^{2}$ Departamento de Biologia Geral, Universidade Federal de Viçosa, \\ Av. P.H. Rolfs s/n, Campus UFV, 36570-900, Viçosa, MG, Brazil. \\ ${ }^{*}$ Corresponding author: tsranzanidasilva@gmail.com \\ ${ }^{2}$ Email: juliocchaul@gmail.com \\ ${ }^{3}$ Email: rsmfeitosa@gmail.com \\ ${ }^{1}$ urn:Isid:zoobank.org:author:3626E013-D17F-4DEE-A753-DB19B067051A \\ ${ }^{2}$ urn:1sid:zoobank.org:author:567D9100-0774-4B6F-87A1-BD6F1E974AC7 \\ ${ }^{3}$ urn:lsid:zoobank.org:author:443A72A7-196F-47FF-A02D-0B5F4B48D8B3
}

\begin{abstract}
In 1887, Mayr described four species of the ant genus Strumigenys collected in the Brazilian state of Santa Catarina: Strumigenys unidentata, Strumigenys subedentata, Strumigenys denticulata, and Strumigenys crassicornis. All of them were described based on a series of one to several specimens, without designation of a holotype, as usual at that time. The same can be said about Strumigenys eggersi, described by Emery in 1890 based on specimens collected in Saint Thomas (U.S. Virgin Islands), without designation of a holotype. In 1961, Brown designated a lectotype for S. unidentata and synonymized it under Strumigenys louisianae. However, the specimens belonging to the type series of the other four species remain as syntypes. Considering that these are four of the most frequently collected species of Strumigenys in the Neotropical region, in this work we provide lectotype designations and complete redescriptions for S. crassicornis, S. denticulata, S. eggersi, and S. subedentata to ensure the taxonomic stability of these names.
\end{abstract}

Keywords. Myrmicine ants, nomenclatural act, taxonomic additions, predatory ants, leaf-litter ants.

Silva T.S.R.D., Chaul J.C.M. \& Feitosa R.M. 2022. Lectotype designation and redescription of four commonly collected Neotropical species of Strumigenys (Hymenoptera: Formicidae). European Journal of Taxonomy 798: 103-126. https://doi.org/10.5852/ejt.2022.798.1673

\section{Introduction}

The hyperdiverse Strumigenys Smith, 1860 is a cosmopolitan genus of ants with more than 850 described species (Bolton 2021), particularly noted for its variation in mandibular morphology (Bolton 2000; Baroni Urbani \& De Andrade 2007; Booher \& Hoenle 2021; Booher et al. 2021). Despite having many 
species occurring in temperate ecosystems, the genus is most diverse in the tropical rainforests around the world (Bolton 1998). In those regions, Strumigenys is often an abundant component of the litter community (Ward 2000).

In terms of regional diversity, the Neotropical region has more than 200 valid species, with possibly several more to be described (Silva \& Feitosa 2019; Bolton 2021). Among them, some species belonging to the gundlachi group (Bolton 2000) are considered the most common ant taxa from the Neotropical Strumigenys fauna. During the work for a catalogue of the Neotropical fauna belonging to the genus, we found some concerning issues related to type designation in four extremely common Neotropical species from the gundlachi group: Strumigenys crassicornis Mayr, 1887, Strumigenys denticulata Mayr, 1887, Strumigenys eggersi Emery, 1890, and Strumigenys subedentata Mayr, 1887.

Issues date back from their original description. Three of the four abovementioned species (i.e., S. crassicornis, $S$. denticulata, and S. subedentata), along with the now synonymized Strumigenys unidentata Mayr, 1887, were described by Mayr (1887) based on several specimens collected by Alfred Hetschko at an unknown locality in the southern state of Santa Catarina, Brazil. In his work, Mayr established the syntypes for the new species based on the specimens studied. Later, Brown (1961) designated a lectotype for S. unidentata and synonymized it under Strumigenys louisianae Roger, 1863. However, no other study has investigated the type status or designated lectotypes for the other three species. In the case of S. eggersi, Emery (1890) provided the description of this species, along with several other species and variants of Strumigenys collected in continental and insular Mesoamerican territories, especially from Costa Rica and Saint Thomas, and did not designate any type category for the specimens used in the description. This has serious implications for the establishment of accurate species boundaries for $S$. crassicornis, $S$. denticulata, S. eggersi, and $S$. subedentata, affecting subsequent revisionary works.

In this work, we provide lectotype designations for $S$. crassicornis, $S$. denticulata, S. eggersi, and $S$. subedentata along with redescriptions based on the designated lectotype for each species and commentaries on morphological variation and distribution of recently collected specimens from Brazil.

\section{Material and methods}

\section{Material}

The material upon which this study is based is located at the following institutions:

CELC = Coleção Entomológica do Laboratório de Sistemática e Biologia de Coleoptera, Universidade Federal de Viçosa, Viçosa, Brazil

DZUP = Coleção Entomológica Padre Jesus Santiago Moure, Universidade Federal do Paraná, Curitiba, Brazil

INPA $=$ Instituto Nacional de Pesquisas da Amazônia, Manaus, Brazil

MCSN $=$ Museo Civico di Storia Naturale 'Giacomo Doria', Genoa, Italy

MCZ = Museum of Comparative Zoology, Cambridge, United States of America

MZSP $=$ Museu de Zoologia da Universidade de São Paulo, São Paulo, Brazil

NHMUK $=$ The Natural History Museum, London, United Kingdom

NHMW = Naturhistorisches Museum, Wien, Austria

ZMHB = Museum für Naturkunde der Humboldt-Universität, Berlin, Germany

Collection curators were contacted indicating that lectotypes and paralectotypes would be designated in their respective institutions. Unique identification codes were generated for each designated specimen per the curatorial requirements of each depository institution; not all specimens received unique identifiers. 


\section{Taxonomic treatment}

Species redescriptions are presented in the format of 'Taxonomic treatments' - i.e., sections of a given publication documenting the features and/or distribution of a related group of organisms in ways adhering to highly formalized conventions (Catapano 2019). The taxonomic treatments are comprised of five subsections (based on the types of semantic content by Schulz \& Jansen 2013): (i) nomenclature (i.e., species name, species name history, and type designations); (ii) diagnosis (i.e., universal statements describing the defining properties shared by all instances of the kind the statement refers to); (iii) measurements and description (i.e., assertional statements that document empirical observations about particular entities); (iv) comments (i.e., contingent statements of sorts, that ascribe predicates to a class that may or may not be true for all its members); and (v) additional material examined.

Diagnoses and redescriptions of the species are elaborated following Oliveira \& Feitosa (2019) and Ladino \& Feitosa (2020); declarations are elaborated following an anterior-posterior axis of description, with sculpture and setae being described first, followed by body structures. The redescriptions are additions and amendments to Bolton's (2000) abbreviated descriptions and are based on the designated lectotypes, with known variation (including those observed in paralectotypes) for each species being described in the commentaries. Morphological and qualitative (i.e., sculpture and setae shape) terms follow Bolton (2000). Digital color images were obtained from AntWeb.org and their corresponding credits are given in the legend of each figure in the following format: attribution, specimen code, photographer, and site address. The measurements and indices used in this study are based on those used by Bolton (2000), Lattke et al. (2018), Booher et al. (2019), Tang et al. (2019), and Brassard et al. (2020). When needed, measurement definitions were amended as to provide unambiguous procedural criteria for standardized measurement procedures. Whenever possible, when images were made available, paralectotypes were measured and their respective measurement values are presented after the lectotype measurements. Additional non-type specimens were also measured, and maximum-minimum values are given. Image measurements were taken using the measurement application ImageJ (Rasband 2018). Measurements are expressed in millimeters to three decimal places, while indices are expressed merely as non-metric units.

\section{List of measurements}

$\mathrm{AB} 4 \mathrm{~L}=$ Abdominal tergite IV length: the length of the fourth abdominal tergite in lateral view, measured from the posterior margin of the postpetiole (i.e., the rim of the postpetiolar foramen) to the posterior margin of the tergite

$\mathrm{DPW}=$ Dorsal petiolar width: the width of the petiolar node measured in dorsal view

$\mathrm{EL} \quad=$ Eye length: the maximum diameter of the compound eye in lateral view. In cases where unpigmented ommatidia are present (generally located at the outer rim of the compound eye), the measure should be taken considering these structures. In cases where the eye is reduced to a single ommatidium, the maximum diameter of this structure alone should be taken

$\mathrm{HL}=$ Head length: the length of the head capsule excluding the mandibles, measured in dorsal view in a straight line from the mid-point of the anterior clypeal margin to the mid-point of the posterior cephalic margin. In species where one or both of these margins is concave, the measurement is taken from the mid-point of a transverse line that spans the apices of the projecting portions

$\mathrm{HT}=$ Head thickness: the thickness of head in lateral view, with maximum distance measured between two parallel lines, one tangent with the dorsal-most point of the head and the other tangent with the ventral-most point of the head. If ventral margin concave upward, then measured from the lower line tangent to the uppermost portion of the curve

HW $=$ Head width: the maximum width of the head in full-face view, excluding the eyes 
ML = Mandible length: the straight-line length of the mandible at full closure, measured in dorsal view from the mandibular apex to the anterior clypeal margin, or to the transverse line connecting the anteriormost points of the clypeus in taxa where the anterior clypeal margin is concave medially

$\mathrm{PH}=$ Petiolar height: maximum distance measured between two parallel lines, one tangent with the node apex and the other tangent with the ventral-most point of the petiole in lateral view. If ventral margin concave upward, then measured from the lower line tangent to the uppermost portion of the curve. If present, spongiform processes ignored

$\mathrm{PL}=$ Petiolar length: the length of the petiole in lateral view, measured from the propodeal foramen to the posterior margin of the petiole (i.e., the rim of the petiolar foramen). If the articulation with the propodeal foramen is obscured by the propodeal lobe, then the measurement is taken from the propodeal lobe to the posterior margin of the petiole

PPL = Postpetiolar length: maximum length of postpetiole in lateral view, measured from the anterior margin to the posterior margin. If present, spongiform processes are ignored

$\mathrm{PW}=$ Pronotal width: the maximum width of the pronotum in dorsal view. In cases where the lower pronotum expands laterally, the measurement is taken from each outermost margins of the lower pronotum. Projecting spines, tubercles or other cuticular prominences at the humeral angles are ignored

$\mathrm{SL}=$ Scape length: the maximum straight line length of the scape, excluding the basal constriction or neck that occurs distal of the condylar bulb

$\mathrm{TL}=$ Total length: the total outstretched length of the ant from the mandibular apex to the gastral apex; the sum of ML + HL + WL + PL + PPL + AB4L

$\mathrm{WL}=$ Weber's length: diagonal length of mesosoma in lateral view, measured from the point at which the pronotum meets the cervical shield to the posterior basal angle of the metapleuron

\section{Indices}

$\mathrm{CI}=$ Cephalic index: HW/HL $\times 100$

DPI $=$ Dorsal petiolar index: DPW/PL $\times 100$

LPI $=$ Lateral petiolar index: $\mathrm{PH} / \mathrm{PL} \times 100$

$\mathrm{MI}=$ Mandibular index: $\mathrm{ML} / \mathrm{HL} \times 100$

$\mathrm{OI}=$ Ocular index: $\mathrm{EL} / \mathrm{HW} \times 100$

$\mathrm{SI}=$ Scape index: SL $/ \mathrm{HW} \times 100$

\section{Results}

Class Insecta Linnaeus, 1758

Order Hymenoptera Linnaeus, 1758

Family Formicidae Latreille, 1809

Subfamily Myrmicinae Lepeletier de Saint-Fargeau, 1835

Genus Strumigenys Smith, 1860

Strumigenys crassicornis Mayr, 1887

Figs 1-2

Strumigenys crassicornis Mayr, 1887: 577.

Neostruma crassicornis - Brown 1948: 111.

Pyramica crassicornis - Bolton 1999: 1672.

Strumigenys crassicornis - Baroni Urbani \& De Andrade 2007: 117. 


\section{Diagnosis}

Strumigenys crassicornis is one of the most easily diagnosable Neotropical Strumigenys and can be distinguished from other species by the combination of lobate scape near subbasal bend (Fig. 2A), spatulate cephalic ground-setae (Fig. 2A), absence of apicoscrobal setae (Fig. 2A), and swollen postpetiole (Fig. 2B).

\section{Type material}

Lectotype (designated herein) (label information) (Fig. 1)

BRAZIL • "St. Cath. Hetschko" [printed]; "Collect. G. Mayr [printed]; "crassicornis" [handwritten] "G. Mayr, Type" [printed]; "Pyramica crassicornis" [handwritten] "det. B. Bolton 1999" [printed]; "Syntype" [printed]; "ANTWEB CASENT0915943" [printed]; "Strumigenys crassicornis Mayr, 1887" LECTOTYPE [printed]; "NHMW-HYM4945” [printed]; NHMW.

Paralectotypes (label information)

BRAZIL - 1 worker; "St. Catharina Coll. G. Mayr" [printed]; "Syntype" [printed]; "Strumigenys crassicornis Mayr, 1887 PARALECTOTYPE" [printed]; "NHMW-HYM4946" [printed]; NHMW • 1 worker; same label information as for preceding; "NHMW-HYM4947" [printed]; NHMW • 1 worker; same label information as for preceding; "NHMW-HYM4948" [printed]; NHMW.

\section{Additional material examined}

BRAZIL - Amazonas • 2 workers; Terra Firme; 02³4' S, 6006' W; 7 Dec. 1990; M.O. de Oliveira leg.; ZF-02, km 10, Capoeira small caps or capital?; CELC, UFV-LABECOL009312. - Bahia • 2 workers; Itacaré; $14^{\circ} 17^{\prime} 38.0^{\prime \prime} \mathrm{S}, 38^{\circ} 59^{\prime} 08.6^{\prime \prime} \mathrm{W}$; 23 Oct. 2015; J. Chaul leg.; CELC, UFV-LABECOL-001967. Espírito Santo • 1 worker; Santa Teresa, "Rebio Augusto Ruschi”" [Augusto Ruschi Biological Reserve], Preguiça [Preguiça Trail]; 1954'42.1" S, 40³2'24.0" W; 800-870 m a.s.l.; Jan. 2013; S. Simon leg.; CELC, UFV-LABECOL-010752. - Mato Grosso - 1 worker; Canarana; $13^{\circ} 04^{\prime}$ S, 52 $23^{\prime}$ W; Jun. 2013; M. Bicalho and V. Ribeiro leg.; Winkler; CELC, UFV-LABECOL-000064. - Minas Gerais •

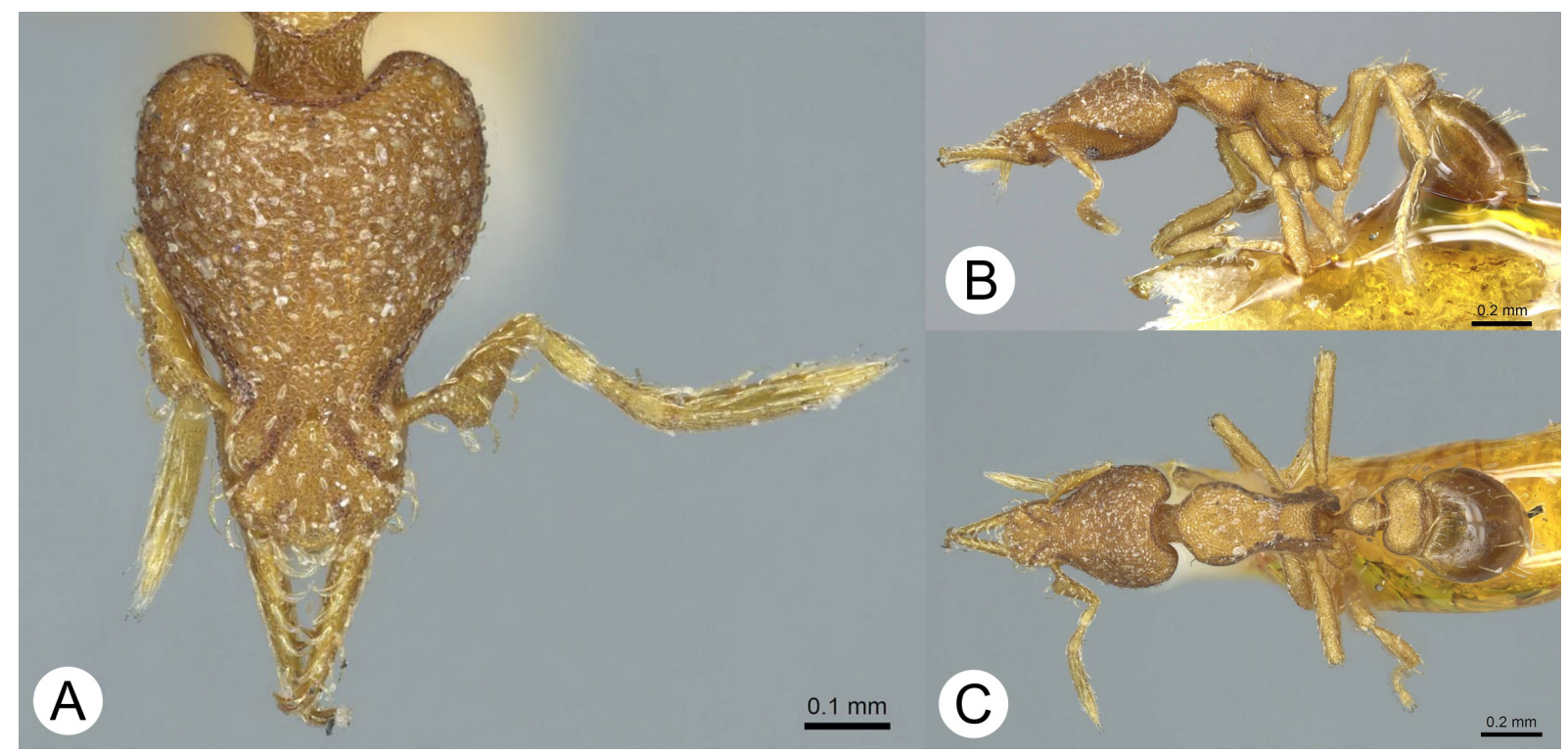

Fig. 1. Lectotype of Strumigenys crassicornis Mayr, 1887 (CC-BY, CASENT0915943, Anna Pal, from www.antweb.org). A. Head, mandibles and antennae, in dorsal view. B. Full body, in lateral view. C. Full body, in dorsal view. 
1 worker; Viçosa; 13 Jan. 1998; A.M. Soares leg.; CELC, UFV-LABECOL-001842 • 1 worker; Viçosa; Feb. 1994; Sperber, Louzada and Lopes leg.; floresta secundária; CELC, UFV-LABECOL-001824 • 1 worker; Viçosa; 14 Nov. 2008-9 Feb. 2009; E.A. Silva and M. Rodrigues leg.; mata do paraíso; CELC, UFV-LABECOL-001838 - 2 workers, 1 queen; same collection data as for preceding; CELC, UFV-LABECOL-010753 - 1 worker, 1 queen; same collection data as for preceding; CELC-UFVLABECOL-011011 • 1 worker; same collection data as for preceding; CELC-UFV-LABECOL-010760 - 1 worker; Viçosa; 2048'08" S, 42 51'31" W, 13-18 Mar. 2011; L. Paolucci leg.; mata do paraíso; Berlese; CELC, UFV-LABECOL-001794 - 1 worker; same collection data as for preceding; CELC-UFV-LABECOL-001764 - 1 worker; same collection data as for preceding; CELC-UFVLABECOL-001793 • 1 worker; same collection data as for preceding; CELC-UFV-LABECOL-001770 - 1 worker; same collection data as for preceding; CELC-UFV-LABECOL-001767 • 1 worker; same collection data as for preceding; CELC-UFV-LABECOL-001782 - 1 worker; same collection data as for preceding; CELC-UFV-LABECOL-001768 • 1 worker; same collection data as for preceding; CELC-UFV-LABECOL-001762 - 1 worker; same collection data as for preceding; CELC-UFVLABECOL-001796 • 1 worker; same collection data as for preceding; CELC-UFV-LABECOL-001774 - 1 worker; same collection data as for preceding; CELC-UFV-LABECOL-001776 • 1 worker; Viçosa; 2009-2010; A.S. Pereira leg.; mata do paraíso; CELC, UFV-LABECOL-001833 • 1 worker, 1 queen; Viçosa; 1 Apr. 2013; J. Chaul leg.; horto; hand sampled; CELC, UFV-LABECOL-001843 • 1 worker;

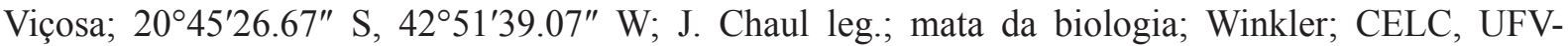
LABECOL-001837 • 2 workers; Viçosa, $20^{\circ} 48^{\prime} 21.6^{\prime \prime} \mathrm{S}, 42^{\circ} 51^{\prime} 10.8^{\prime \prime} \mathrm{W} ; 780 \mathrm{~m}$ a.s.1.; 1 May 2013; J. Chaul and R.S. Jesus leg.; mata do paraíso; hypogaeic Winkler; CELC, UFV-LABECOL-1822 • 1 queen; same collection data as for preceding 11 worker; Viçosa; $20^{\circ} 48^{\prime} \mathrm{S}, 42^{\circ} 51^{\prime} \mathrm{W}$; 12 Feb. 2015; J. Chaul and A.P. Alves leg.; mata do paraíso; Winkler; CELC, UFV-LABECOL-001841 • 1 queen; Viçosa; 2048'19" S, 4251'13.1" W; 685 m a.s.1.; 12 Jul. 2016; A.P. Raimundo, L. Ferreira, J. Chaul and L. Paolucci leg.; mata do paraíso; hypogaeic Winkler; CELC, UFV-LABECOL-010759 • 1 worker; same collection data as for preceding; CELC, UFV-LABECOL-010756 • 1 worker; same collection data as for preceding; CELC, UFV-LABECOL-010757 • 1 worker; same collection data as for preceding; CELC, UFV-LABECOL-010758 - 1 worker; same collection data as for preceding; CELC, UFVLABECOL-010761 • 1 worker; same collection data as for preceding; CELC, UFV-LABECOL-010762 - 1 worker; Araponga; Apr. 2011; D. Muscardi leg.; CELC, UFV-LABECOL-001849 • 1 worker, ; Parque Estadual da Serra do Brigadeiro; 20 $39^{\prime} 16^{\prime \prime}$ S, 42 $24^{\circ} 58^{\prime \prime}$ W; 1400 m a.s.l.; Jan. 2007; R. Solar leg.; CELC, UFV-LABECOL-009313 - 2 workers, 1 queen; same collection data as for preceding; CELC, UFV-LABECOL-00145 - 4 workers; same collection data as for preceding; CELC, UFVLABECOL-0018200 - 2 workers; Araponga-Fervedouro, "Serra do Brigadeiro"; 2044'21.9" S, $42^{\circ} 27^{\prime} 20.6^{\prime \prime} \mathrm{W} ; 16$ Oct. 2016; N. Safar and T. Fernandes leg.; Serra do Brigadeiro; CELC, UFVLABECOL-009314 • 2 workers; same collection data as for preceding; CELC, UFV-LABECOL-009311 - 1 worker; Alto Caparaó, Vale Verde; 6 Nov. 2016; A. Orsetti and S. Alóquio leg.; Winkler; CELC, UFVLABECOL-009309 1 worker; same collection data as for preceding; CELC, UFV-LABECOL-009310 • 1 queen; Providência; 2140'43.7" S, 42³8'19.0" W; Dec. 2012; J. Chaul leg.; Fazenda Araribá; Winkler; CELC, UFV-LABECOL-001835 • 1 worker, 1 queen; Parque Estadual do Itacolomi; 20²5'34.8" S, 43³0'53.7" W; 25-31 Oct. 2016; G. Soares, J. Falcon, L.F. Climaco and T. Pontes leg.; grotão; CELC, UFV-LABECOL-010729 • 2 workers; Serra do Cipó "Próx. Cachoeira da Capivara" [near Cachoeira

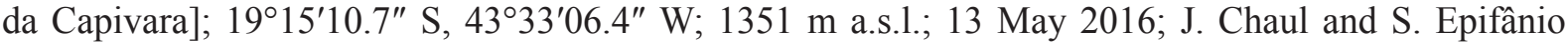
leg.; CELC, UFV-LABECOL-001909 • 1 worker; same collection data as for preceding; CELC, UFVLABECOL-001906 • 1 worker; Ipaba, "Faz. Macedônia" [Macedônia Farm]; Nov. 2005; T. Marques leg.; CELC, UFV-LABECOL-001819. - Pará • 2 workers; Primavera; 0058’45" S, 4706’ 43" W; 5-6 Nov. 2018; L.P. Prado and K.L.S. Sampaio leg.; Winkler; CELC, UFV-LABECOL-010463・1 worker; same collection data as for preceding; CELC, UFV-LABECOL-011010. - Rondônia • 1 worker; Jaci Novo; 6 Jul. 2013; km 3; INPA, ANTWEB1032004. - Santa Catarina • 2 workers; Indaial, Parque Nacional da Serra do Itajaí, Faxinal do Bepe; Feb. 2015; M.D. Vitorino leg.; regeneração; DZUP • 
3 workers; same collection data as for preceding; Apr. 2015; DZUP • 1 worker; same collection data as for preceding; Jun. 2015; DZUP • 2 workers; same collection data as for preceding; Aug. 2015; DZUP • 2 workers; same collection data as for preceding; Feb. 2016; DZUP • 3 workers; same collection data as for preceding; Aug. 2016; DZUP • 1 worker; same collection data as for preceding; Aug. 2015; floresta; DZUP • 1 worker; same collection data as for preceding; Aug. 2015; poleiro; DZUP • 1 worker; same collection data as for preceding; Jun. 2016; DZUP • 2 workers; same collection data as for preceding; Feb. 2016; galharia; DZUP • 1 worker; same collection data as for preceding; Aug. 2016; DZUP • 3 workers; same collection data as for preceding; Aug. 2016; plantio; DZUP • 2 workers; Painel, Base Avançada do IBAMA; 18 May 2013; R.M. Feitosa leg.; solo; DZUP • 1 worker; Três Barras, Floresta Nacional de Três Barras; 26¹3'48.444" S, 50¹7'45.21" W; 723.513 m a.s.1.; 25 Apr. 2015; D.C. Ortiz and J. Niemyer leg.; DZUP • 1 worker; Três Barras, Floresta Nacional de Três Barras; 26 $07^{\prime} 35.56^{\prime \prime}$ S, 50¹8'51.17" W; 15 Dec. 2014; D.C. Ortis et al. leg.; DZUP • 1 worker; Seara; 1999; R. Silva leg.; MZSP, ANTWEB1032393 - 1 worker; Araranguá, Restinga Morro dos Conventos; 7-23 Jan. 2008; D.C. Cardoso and M.P. Cristiano leg.; CELC, UFV-LABECOL-001893. - São Paulo - 1 worker; Salesópolis, Estação Ecológica de Boracéia; 2339'19.0" S, 4553'17.0" W; 3-11 Nov. 2017; R.P.S. Almeida and J.A. Silva leg.; Winkler; CELC, UFV-LABECOL-010754.

\section{Lectotype measurements}

ABD4L 0.396; DPW 0.124; EL 0.052; HL 0.585; HT 0.288; HW 0.412; ML 0.230; PH 0.132; PL 0.277; PPL 0.149; PW 0.279; SL 0.201; WL 0.589; TL 1.954; CI 70.4; DPI 44.7; LPI 47.6; MI 39.3; OI 12.6; SI 48.8 .

\section{Non-type measurements}

ABD4L 0.330-0.470; DPW 0.105-0.150; EL 0.040-0.060; HL 0.480-0.620; HT 0.250-0.330; HW 0.340-0.450; ML 0.155-0.240; PH 0.130-0.190; PL 0.220-0.340; PPL 0.110-0.200; PW 0.2300.325 ; SL $0.210-0.310$; WL $0.465-0.630$; TL $1.765-2.500$; CI 70.1-78.8; DPI 39.7-50.0; LPI 48.361.4; MI 32.3-38.7; OI 9.8-14.6; SI 53.8-70.6 ( $\mathrm{n}=14)$.

\section{Description}

SCULPTURE. Head entirely reticulate-punctate, including antennal scrobe. Mesosoma mostly reticulatepunctate, katepisternum partly smooth (Fig. 2B). Fourth abdominal tergite entirely smooth, except for basigastral costulae. Basigastral costulae short; in dorsal view, its length about a third of postpetiole length.

SetAe. Cephalic and mesosomal ground-setae spatulate (Fig. 2A). Metasomal setae elongate-spatulate to remiform. Apicoscrobal setae absent (Fig. 2A). Pair of erect setae on cephalic dorsum close to occipital margin present. Anterior margin of scape with one or more spatulate setae curved towards antennal insertion. Humeral setae absent and mesonotal setae present (but see Comments below).

HEAD. Masticatory margin of mandible with three to five denticles between apicodorsal tooth and submedian tooth, with two to four denticles proximal of submedian tooth (Fig. 2A). Apex of mandible with unknown number of intercalary denticles (but see Fig. 2A and Comments section for variation). Anterior clypeal margin, in dorsal view, slightly angular and projecting anteriorly. Eye, in lateral view, with four to five ommatidia in longest row. Eye on anterior half of head. In dorsal view, scape narrows basally; anterior margin expanded and almost lobate near subbasal bend. Third flagellomere smaller than fourth flagellomere; length of former only a third of length of latter.

Mesosoma. Humerus with small angular projection. Dorsum of mesonotum, in lateral view, slightly higher than dorsum of pronotum. Metanotal groove weakly impressed. Propodeal spine relatively long and triangular, linked to propodeal lobe by narrow lamella that extends throughout propodeal declivity. Femoral bulla ovate and located distally on dorsal margin of sclerite. 
Metasoma. Petiolar node, in dorsal view, slightly wider than long; in lateral view, anterior margin slightly longer than dorsal margin. Postpetiole, in lateral view, swollen and globular. Anterior margin of postpetiole, in dorsal view, medially concave. Ventral spongiform process of petiole absent. Ventral spongiform lobe of postpetiole minute to absent (Fig. 2B). Lateral spongiform lobe of postpetiole reduced to a narrow lamella (Fig. 2B). Ventral basigastral spongiform pad (= specialized setae on fourth abdominal sternite) small.

\section{Comments}

Bolton (2000) considered S. crassicornis as a member of the crassicornis complex (i.e., a cluster of species in the gundlachi species group), along with Strumigenys aethegenys (Bolton, 2000), S. auctidens (Bolton, 2000), S. brevicornis Mann, 1922, S. crementa (Bolton, 2000), S. metopia (Brown, 1959), S. myllorhapha (Brown, 1959), S. pasisops (Bolton, 2000), S. stenotes (Bolton, 2000), and S. zeteki (Brown, 1959). Members of the crassicornis complex are defined by the following traits (Bolton 2000): (i) inner margin of mandible with a submedian tooth or denticle near midlength; (ii) inner margin of mandible with smaller teeth between apicodorsal tooth and submedian tooth; (iii) three to five intercalary teeth; (iv) labral lobes long and slender; and (v) setae on apices of labral lobes short (i.e., with the same size or shorter than the labral lobes).

According to Bolton (2000), different series of this species show slight variation in setae and sculpture, although maintaining the diagnostic traits for the species. He mentioned that some specimens possibly have short filiform humeral setae, although this condition was not observed in the type specimen and a few other individuals observed in this study. Additionally, a pair of mesonotal erect simple setae, which was not mentioned by Mayr (1887) nor Bolton (2000) in their descriptions, was also observed in the lectotype and a few other specimens. Humeral and mesonotal setae are apparently lost during the lifetime of the ants, since many specimens, otherwise well preserved, did not have those setae and most of the ones which did have them appear to be young adults by the appearance of their cuticle. Also, some specimens had an extremely reduced lateral spongiform lobe in the postpetiole, appearing vestigial, agreeing with the description made by Bolton (2000).

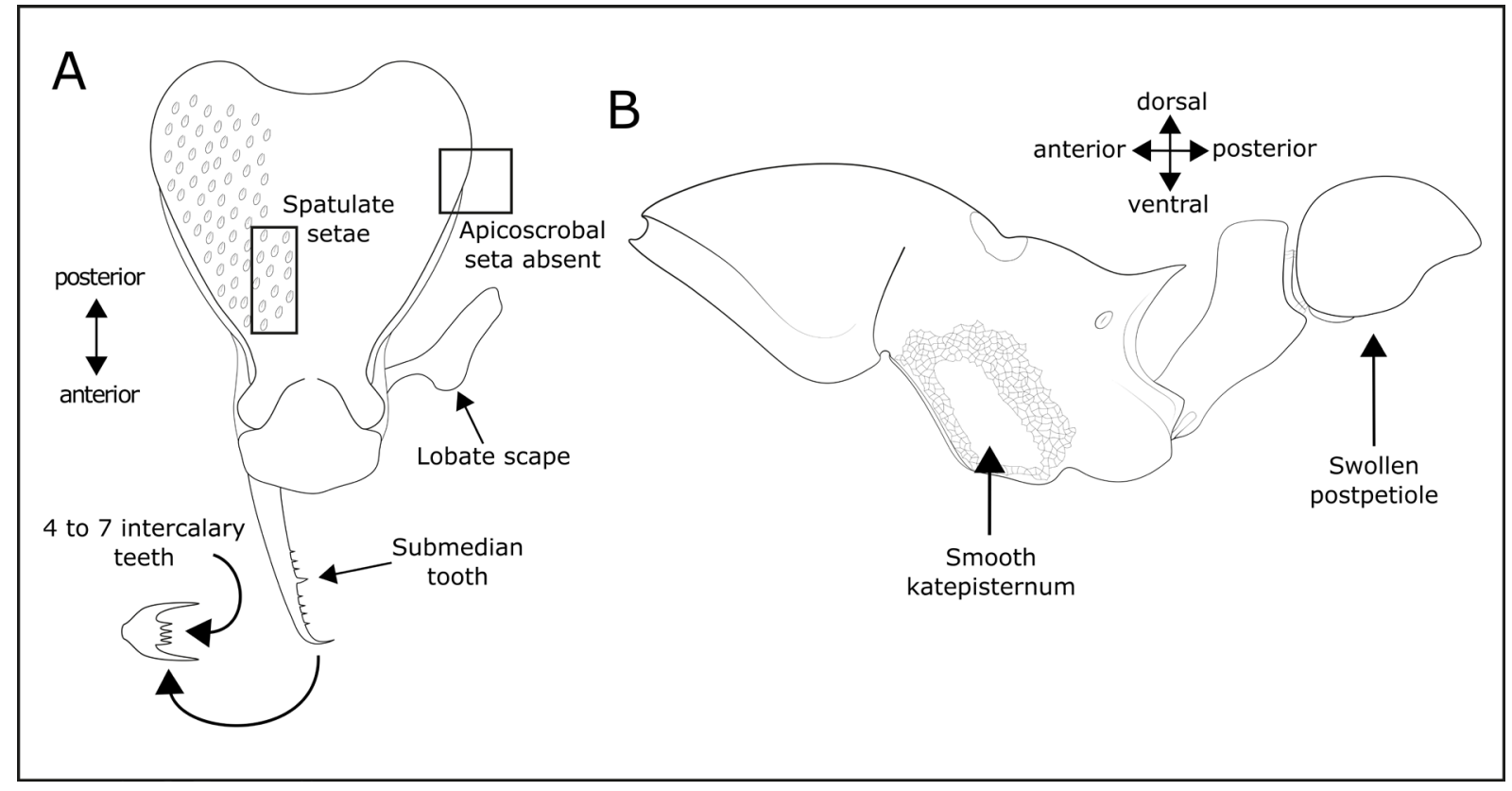

Fig. 2. Generalized schematics of Strumigenys crassicornis Mayr, 1887, showing useful identification features. A. Head in dorsal view. B. Mesosoma, petiole, and postpetiole in lateral view. 
In Bolton's (2000) description, the author mentions that S. crassicornis have three to four minute intercalary teeth. Since we did not had access to the physical lectotype specimen, we could not confirm this condition. However, while studying other non-type specimens, we observed that the intercalary dentition consists of up to six to seven teeth. Interestingly, these intercalary teeth count does not agree with the diagnosis proposed by Bolton (2000) for the crassicornis complex.

In specimens collected in Orleans and Tunas do Paraná (cf. list of examined materials), the katepisternum appears entirely reticulate-punctate, without smooth patches whatsoever. Different specimens collected in the same square meter (from Winkler leaf-litter samples) possess both reticulate-punctate katepisternum and various degrees of smoothness. One specimen from Viçosa (Minas Gerais State) and one specimen from the Reserva Biólogica Augusto Ruschi (Espírito Santo State) also have an entirely reticulate-punctate katepisternum. In Viçosa, all the other specimens examined matched the lectotype in having a smooth katepisternum. The morphological variability in this particular character, summed with the higher intercalary teeth count found in some non-type specimens observed, reinforces the need for a reevaluation of the boundaries of this species.

In the Amazonian region, non-type specimens identified as $S$. crassicornis tend to depart further from the lectotype, differing in one or more traits, and do not entirely match the species' diagnosis. One specimen from Primavera (Pará State) has shallow reticulation on fourth abdominal tergite. A couple of specimens from Amazonas state (vicinities of Manaus; cf. additional material examined ZF-02) have an almost entirely reticulate-punctate katepisternum and shallow reticulation on fourth abdominal tergite. A specimen from Canarana (Mato Grosso State) has shallow reticulation on fourth abdominal tergite and humeral and mesonotal setae which are not simple, but slightly flattened and subflagellate. A couple of specimens, also from Primavera, have shallow reticulation on fourth abdominal tergite, basigastral costulae absent, spongiform process on postpetiole absent, and smaller and less abundant metasomal erect setae. Finally, one specimen from "Jaci Novo" (Rondônia State) is much larger than all examined specimens, has both humeral and mesonotal setae flattened and subflagellate, and a comparatively larger postpetiole, with shallow reticulation on fourth abdominal tergite.

Strumigenys denticulata Mayr, 1887

Figs 3-4

Strumigenys denticulata Mayr, 1887: 576.

Pyramica aschnae Makhan, 2007: 2, figs 3-4 (synonymyzed by Bolton et al. 2008).

Pyramica aschnakiranae Makhan, 2007: 3, figs 5-6 (synonymyzed by Bolton et al. 2008).

Pyramica denticulata - Bolton 1999: 1672.

Strumigenys denticulata - Baroni Urbani \& De Andrade 2007: 117.

\section{Diagnosis}

Strumigenys denticulata can be distinguished from other local species by the combination of long mandibles, flagellate humeral setae (Fig. 4B), reduced postpetiolar spongiform projections (Fig. 4B), and fourth abdominal tergite mostly smooth.

\section{Type material}

Lectotype (designated herein) (label information) (Fig. 3)

BRAZIL - "St. Cath Hetschko" [printed]; "Collect. G. Mayr" [printed]; "denticulata" [handwritten] "G. Mayr, Type" [printed]; “ANTWEB CASENT 0915944” [printed]; "Strumigenys denticulata Mayr, 1887 LECTOTYPE” [printed]; "NHMW-HYM4949” [printed]; NMHW. 
Paralectotypes (label information)

BRAZIL - 1 worker; same collection data as for lectotype; "Strumigenys denticulata Mayr, 1887 PARALECTOTYPE” [printed]; "MCZT_28511" [printed]; MCZ • 2 workers; "Blumenau" [printed]; "Coll. G. Mayr, Type" [printed]; "Strumigenys denticulata Mayr, 1887 PARALECTOTYPE" [printed]; "NHMW-HYM4952" [printed]; NHMW • 1 worker; "St. Catharina Coll. G. Mayr [printed]; "Type" [printed]; "Strumigenys denticulata Mayr, 1887 PARALECTOTYPE" [printed]; "NHMW-HYM4950" [printed]; NMHW • 1 worker; "St. Catharina Coll. G. Mayr" [printed]; "126 Hetschko 1/984" [handwriten] "Type" [printed]; "Strumigenys denticulata Mayr, 1887 PARALECTOTYPE" [printed]; "NHMWHYM4951" [printed]; NHMW • 1 worker; "St. Catharina Coll. G. Mayr" [printed]; "Brit. Mus. 1922501." [printed]; "denticulata" [handwritten] "G. Mayr, Type" [printed]; "BMNH(E)1013551" [printed]; “ANTWEB CASENT 0900180" [printed]; "Syntype" [printed] "Strumigenys denticulata Mayr, 1887 PARALECTOTYPE” [printed]; NHMUK.

\section{Additional material examined}

BRAZIL - Amazonas • 4 workers, 1 queen; Terra Firme; 02 ${ }^{\circ} 34^{\prime}$ S, $60^{\circ} 06^{\prime}$ W; 7 Nov. 1990; M.O. de Oliveira leg.; capoeira; km 10; ZF-02; CELC, UFV-LABECOL-009312 • 1 worker; Manaus, Colosso Camp; 2²4'17.6" S, 59 53'37.6" W; 12-21 Aug. 2016; B. Boudinot, I. Fernandes and J. Chaul leg.; CELC, ANTWEB1038943 - Bahia • 2 workers, 2 queens; Itacaré; 14¹7'38.0" S, 38 59'08.6" W; 23 Oct. 2015; J. Chaul leg.; CELC, UFV-LABECOL-001970. - Espírito Santo • 1 worker; Conceição da Barra, Reserva Biológica Córrego Grande; 18¹5'18.3" S, 3949'04.0" W; 33 m a.s.1.; 21 Apr.-10 May 2017; N. Safar, C. Aquila and C. Guimarães leg.; Winkler; CELC, ANTWEB1032525 • 1 worker, 1 queen; Conceição da Barra, Floresta Nacional do Rio Preto; $18^{\circ} 24^{\prime} 31.4^{\prime \prime}$ S, $39^{\circ} 50^{\prime} 00.9^{\prime \prime}$ W; 33 m a.s.1.; 21 Apr.10 May 2017; N. Safar, C. Aquila and C. Guimarães; Winkler; CELC, UFV-LABECOL-0008497. - Mato Grosso • 1 worker; Canarana-Querência; $13^{\circ} 04^{\prime}$ S, 52 $2^{\circ} 23^{\prime}$ W; Jun. 2013; M. Bicalho and V. Ribeiro leg.; Winkler; CELC, UFV-LABECOL-001884. - Minas Gerais • 1 worker; São Tiago; 20 $57^{\prime} 09.69^{\prime \prime}$ S, 4426'32.09" W; Feb. 2012; M. Padilha leg.; CELC, UFV-LABECOL-010975 • 1 queen; same collection data as for preceding; CELC, UFV-LABECOL-001878 • 1 queen; Viçosa; 13 Jan. 1998; S.M. Soares leg.; CELC, UFV-LABECOL-001889 • 1 worker; Viçosa, Mata do Paraíso; 2009-2010; A.S. Pereira leg.; CELC, UFV-LABECOL-001855 • 1 queen; same collection data as for preceding; CELC, UFVLABECOL-001854 • 1 queen; same collection data as for preceding; CELC, UFV-LABECOL-001888 - 3 queens; same collection data as for preceding; CELC, UFV-LABECOL-001733 • 1 worker; Viçosa; Jan. 2011; L.G. Dornelas leg.; CELC, UFV-LABECOL-001817 • 1 worker; Viçosa, Mata do Paraíso; $20^{\circ} 48^{\prime} 08^{\prime \prime}$ S, 42 51'31" W; 13-18 Mar. 2011; L. Paolucci leg.; Berlese; CELC, UFV-LABECOL-001786 - 1 worker; same collection data as for preceding; CELC, UFV-LABECOL-001680 • 1 worker; same collection data as for preceding; CELC, UFV-LABECOL-001772 1 worker; same collection data as for preceding; CELC, UFV-LABECOL-001760 • 1 worker; same collection data as for preceding; CELC, UFV-LABECOL-001777 • 1 worker; same collection data as for preceding; CELC, UFVLABECOL-001773 • 1 worker; same collection data as for preceding; CELC, UFV-LABECOL-001763 - 1 worker; same collection data as for preceding; CELC, UFV-LABECOL-001787 • 1 worker; same collection data as for preceding; CELC, UFV-LABECOL-001785 1 worker; same collection data as for preceding; CELC, UFV-LABECOL-001784 • 1 worker; Viçosa; 2047'44.2" S, 4250'47.6" W; 15 Feb. 2006; F.A. Schmidt leg.; CELC, UFV-LABECOL-001694 • 1 worker; Viçosa, Mata do Seu Nico; $20^{\circ} 47^{\prime} 54.5^{\prime \prime}$ S, 42 ${ }^{\circ} 50^{\prime} 49.9^{\prime \prime}$ W; 745 m a.s.1.; 13 Apr. 2012; F.A. Schmidt, F.M. Rezende and R.S. Jesus leg.; CELC, UFV-LABECOL-001747 • 1 worker, 1 queen; Viçosa, Horto UFV; 8 Feb. 2012; J. Chaul leg.; CELC, UFV-LABECOL-001887 • 1 worker, 1 queen; $20^{\circ} 45^{\prime} 30.44^{\prime \prime} \mathrm{S}, 42^{\circ} 51^{\prime} 49.65^{\prime \prime} \mathrm{W}$; $731 \mathrm{~m}$ a.s.1.; 5 May 2013; J. Chaul and N. Safar leg.; epigaeic Winkler; CELC, UFV-LABECOL-008836 1 queen; Viçosa, Mata do Paraíso; $20^{\circ} 48^{\prime}$ S, 42 ${ }^{\circ}$ 51' W; 12 Feb. 2015; J. Chaul and A.P. Alves leg.; Winkler; CELC, UFV-LABECOL-001715 • 1 worker; Viçosa, Mata dos Cristais; 2046'36.84" S, 42 $50^{\circ} 31.56^{\prime \prime} \mathrm{W}$; Apr. 2013; J. Chaul and R.S. Jesus leg.; CELC, UFV-LABECOL-008220 • 2 workers; Viçosa, Mata do Paraíso; 2048'18.1" S, 4251'05.5" W; May 2014; R. Jesus leg.; CELC, UFV-LABECOL-000066 • 
1 worker; Viçosa, Mata do Paraíso; 2048'19" S, 4251'12" W; 12 Jul. 2016; A.P. Raimundo, L. Ferreira, J. Chaul and L. Paolucci leg.; hypogaeic Winkler; CELC, UFV-LABECOL-010979 • 1 worker; same collection data as for preceding; CELC, UFV-LABECOL-010978 1 worker; same collection data as for preceding; CELC, UFV-LABECOL-010977 • 1 worker; same collection data as for preceding; CELC, UFV-LABECOL-010976 • 1 worker; Viçosa, Mata do Paraíso; 2048’08.4" S, 4251'31.1" W; 16 Feb. 2018; F. Ferreira leg.; CELC, UFV-LABECOL-009450 • 1 queen; Viçosa, Mata do Paraíso;

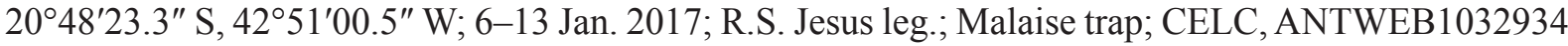
- 1 worker; Araponga; Apr. 2011; D. Muscardi; CELC, UFV-LABECOL-001894 • 1 worker, 1 queen; Araponga, Cachoeira do Boné; 20³9'43" S, 42²6'57.5" W; 11 Feb. 2016; J. Chaul leg.; CELC, UFVLABECOL-001536 - 2 workers; Araponga, Parque Estadual da Serra do Brigadeiro, Estrada ArapongaFervedouro; 2044'21.9" S, 42²7'20.6" W; 16 Oct. 2016; N. Safar and T. Fernandes leg.; CELC, UFVLABECOL-009314 • 1 worker; Timóteo, Parque Estadual do Rio Doce; 1946' S, 42³7' W; 2009; F.A. Schmidt leg.; CELC, UFV-LABECOL-001857 • 1 worker, 1 queen; Parque Estadual do Itacolomi; 20²5'36.1" S, 4330'23.3" W; 25-31 Oct. 2016; G. Soares, J. Falcon, L.F. Climaco and T. Pontes leg.; CELC, UFV-LABECOL-010729 • 1 worker; Parna do Cipó, Cachoeira da Farofa; 19²2'45.9" S, 43³4'32.8" W; 11 May 2016; J. Chaul leg.; CELC, UFV-LABECOL-011008 • 1 worker; same collection data as for preceding; CELC, UFV-LABECOL-011009 • 1 worker; Conceição do Mato Dentro, Serra da Serpentina; $19.03394^{\circ}$ S, $43.33687^{\circ}$ W; 1-7 Sep. 2010; R.R. Silva leg.; Winkler; CELC, UFVLABECOL-010460 • 1 worker; same collection data as for preceding; CELC, UFV-LABECOL-010462 - 1 worker; Ipaba, Reserva Particular do Patrimônio Natural Fazenda Macedônia, CENIBRA; Nov. 2005; T. Marques leg.; CELC, UFV-LABECOL-001875. - Pará • 1 worker; Paragominas; Jan.-Jul. 2011; R. Solar leg.; CELC, UFV-LABECOL-001722 • 1 worker; Primavera; 01 $00^{\prime} 36^{\prime \prime}$ S, 47 $07^{\circ} 04^{\prime \prime}$ W; 5-6 Nov. 2018; L.P. Prado and K.L.S. Sampaio; Winkler; CELC, UFV-LABECOL-010477 • 2 workers; Portel; 01 ${ }^{\circ} 50^{\prime} 31.3^{\prime \prime}$ S, 50³7'44.4" W; 5 Jun. 2016; E.L.S. Siqueira and team leg.; Winkler; CELC, UFVLABECOL-010449. - Paraná • 22 workers; Tunas do Paraná, Parque Estadual das Lauráceas, Trilha da Anta; 2451'27.53" S, 4843.2'58" W; 2-4 May 2017; T.S.R. Silva, N. Ladino, R.M. Feitosa leg.;

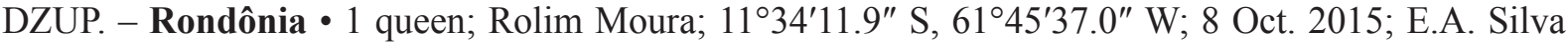

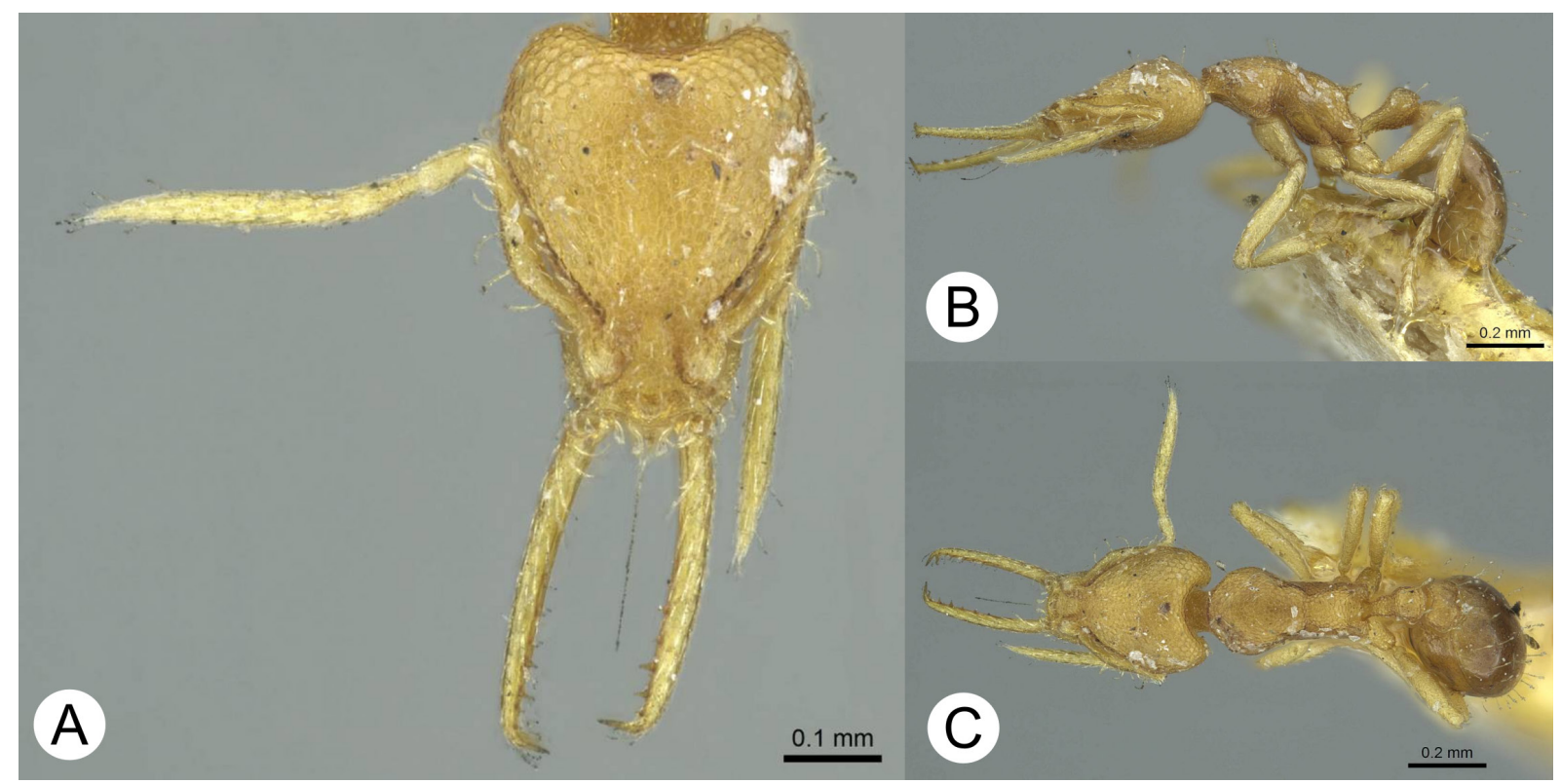

Fig. 3. Lectotype of Strumigenys denticulata Mayr, 1887 (CC-BY, CASENT0915944, Anna Pal, from www.antweb.org). A. Head, mandibles and antennae, in dorsal view. B. Full body, in lateral view. C. Full body, in dorsal view. 
leg.; CELC, UFV-LABECOL-011006. - Santa Catarina • 1 worker; Parque Estadual Serra Dourada; $28^{\circ} 10^{\prime} 38^{\prime \prime}$ S, 49²3'38,94" W; 31 May 2014; A.S. Pereira leg.; A3W05; DZUP • 1 worker; Orleans, Parque Estadual da Serra Furada; 28 10'38" S, 49²3'38.94" W; 31 May 2014; A.S. Pereira leg.; A3W05; DZUP • 1 worker; same collection data as for preceding; 24 Mar. 2014; A3W06; DZUP • 1 worker,

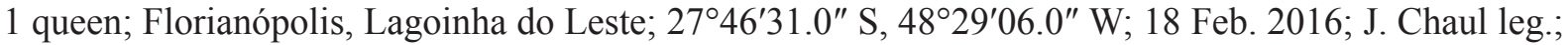
CELC, UFV-LABECOL-008223. - São Paulo • 1 worker; Parque Estadual da Serra do Mar; $23^{\circ} 21^{\prime}$ S, 4451’ W; 2009; F.A. Schmidt leg.; CELC, UFV-LABECOL-001853.

PERU - Madre de Dios - 1 worker; Puerto Maldonado, Reserva Nacional Tambopata; $12^{\circ} 51^{\prime} 21^{\prime \prime} \mathrm{S}$ 69²1'43" W; 210 m a.s.1.; 19-31 Jul. 2012; R. Feitosa leg.; CELC.

\section{Lectotype measurements}

ABD4L 0.321; DPW 0.078; EL 0.033; HL 0.418; HT 0.221; HW 0.321; ML 0.355; PH 0.106; PL 0.172; PPL 0.115; PW 0.226; SL 0.236; WL 0.441; TL 1.816; CI 77.9; DPI 45.3; LPI 61.6; MI 84.9; OI 10.3; SI 73.5 .

\section{Paralectotype measurements}

ABD4L N/A; DPW 0.094; EL 0.035; HL 0.405; HT 0.218; HW 0.33; ML 0.308; PH 0.104; PL 0.185; PPL N/A; PW 0.228; SL 0.232; WL 0.462; TL N/A; CI 81.5; DPI 50.8; LPI 56.2; MI 76; OI 10.6; SI 70.3 $(\mathrm{n}=1$; NHMUK BMNH(E)1013551; see Comments for missing measurement values).

\section{Non-type measurements}

ABD4L 0.280-0.370; DPW 0.080-0.105; EL 0.040-0.050; HL 0.400-0.450; HT 0.220-0.250; HW 0.320-0.365; ML 0.280-0.370; PH 0.100-0.115; PL 0.170-0.200; PPL 0.080-0.090; PW 0.2200.250 ; SL $0.230-0.280$; WL $0.420-0.480$; TL 1.660-1.895; CI 76.2-81.8; DPI 47.1-55.6; LPI 54.161.8; MI 70.0-88.1; OI 11.8-13.7; SI 70.8-84.4 $(\mathrm{n}=10)$.

\section{Description}

SCULPTURE. Head entirely reticulate-punctate, including antennal scrobe. Mesosoma entirely reticulatepunctate, except for katepisternum and part of metapleura, which are smooth (Fig. 4B). Fourth abdominal tergite superficially reticulate-punctate near base. Length of basigastral costulae, in dorsal view, more or less equal to length of postpetiole.

Setae. Cephalic ground-setae remiform (Fig. 4A). Two pairs of remiform erect setae on cephalic dorsum; one pair near medial region of head, other near occipital margin. Apicoscrobal setae flagellate (Fig. 4A). Anterior margin of scape with one or more remiform setae curved towards antennal insertion. Humeral setae flagellate (Fig. 4B). Erect setae on antero-medial region of pronotum absent. Pair of erect setae on mesonotum stiff, simple to slightly remiform. Setae on petiole, postpetiole and fourth abdominal tergite remiform to slightly clavate.

HEAD. Masticatory margin of mandible with 5-10 preapical denticles (Fig. 4A). Apex of mandible with two minute intercalary denticles (Fig. 4A). Anterior clypeal margin, in dorsal view, convex medially. Eye, in lateral view, with three to four ommatidia along longest row. Eye on anterior half of head. In dorsal view, scape cylindrical. Third flagellomere smaller than fourth flagellomere; length of former only one-third of length of latter.

Mesosoma. Humerus with small angular projection. Dorsum of mesonotum, in lateral view, convex, confluent with dorsum of pronotum. Metanotal groove weakly impressed, almost absent in lateral view. Propodeal spine relatively long and triangular, linked to propodeal lobe by narrow carina that extends 
throughout propodeal declivity. Femoral bulla small, ovate and located distally on dorsal margin of sclerite.

Metasoma. Petiolar node, in dorsal view, slightly wider than long, almost as long as wide; in lateral view, anterior margin almost as long as dorsal margin. Anterior margin of postpetiole, in dorsal view, concave. Lateral and ventral spongiform processes of petiole absent. Ventral spongiform lobe of postpetiole minute (Fig. 4B). Lateral spongiform lobe of postpetiole vestigial (Fig. 4B). Ventral basigastral spongiform pad absent.

\section{Comments}

Bolton (2000) considered S. denticulata as a member of the gundlachi complex (i.e., a cluster of species under the gundlachi species group), along with Strumigenys connectens Kempf, 1958, S. decipula (Bolton, 2000), S. eggersi Emery, 1890, S. enopla (Bolton, 2000), S. gemella Kempf, 1975, S. gundlachi (Roger, 1862), S. jamaicensis Brown, 1959, S. laevipleura Kempf, 1958, S. lalassa (Bolton, 2000), S. nubila Lattke \& Goitía, 1997, S. subedentata Mayr, 1887, S. trieces Brown, 1960, S. vartana (Bolton, 2000), and S. xenognatha Kempf, 1958. Members of the gundlachi complex are defined by the following traits (Bolton 2000): (i) inner margin of mandible without a submedian tooth or denticle near midlength; (ii) inner margin of mandible with several teeth of different sizes posterior to the apicodorsal tooth; (iii) two (rarely three) intercalary teeth; (iv) labral lobes short; and (v) setae on apices of labral lobes long (i.e., longer than the labral lobes).

According to Bolton (2000), specimens belonging to $S$. denticulata have a wide range of mandibular length variation, with individuals collected in a single leaf litter sample presenting MIs ranging from 72 to 85 . It is important to notice that the MI of the lectotype falls near the maximum value established by Bolton (i.e., MI 84.9). On the other hand, ML and HL measurements fall well within the range proposed by the same author as diagnosable for the species (i.e., ML 0.355 and HL 0.418).

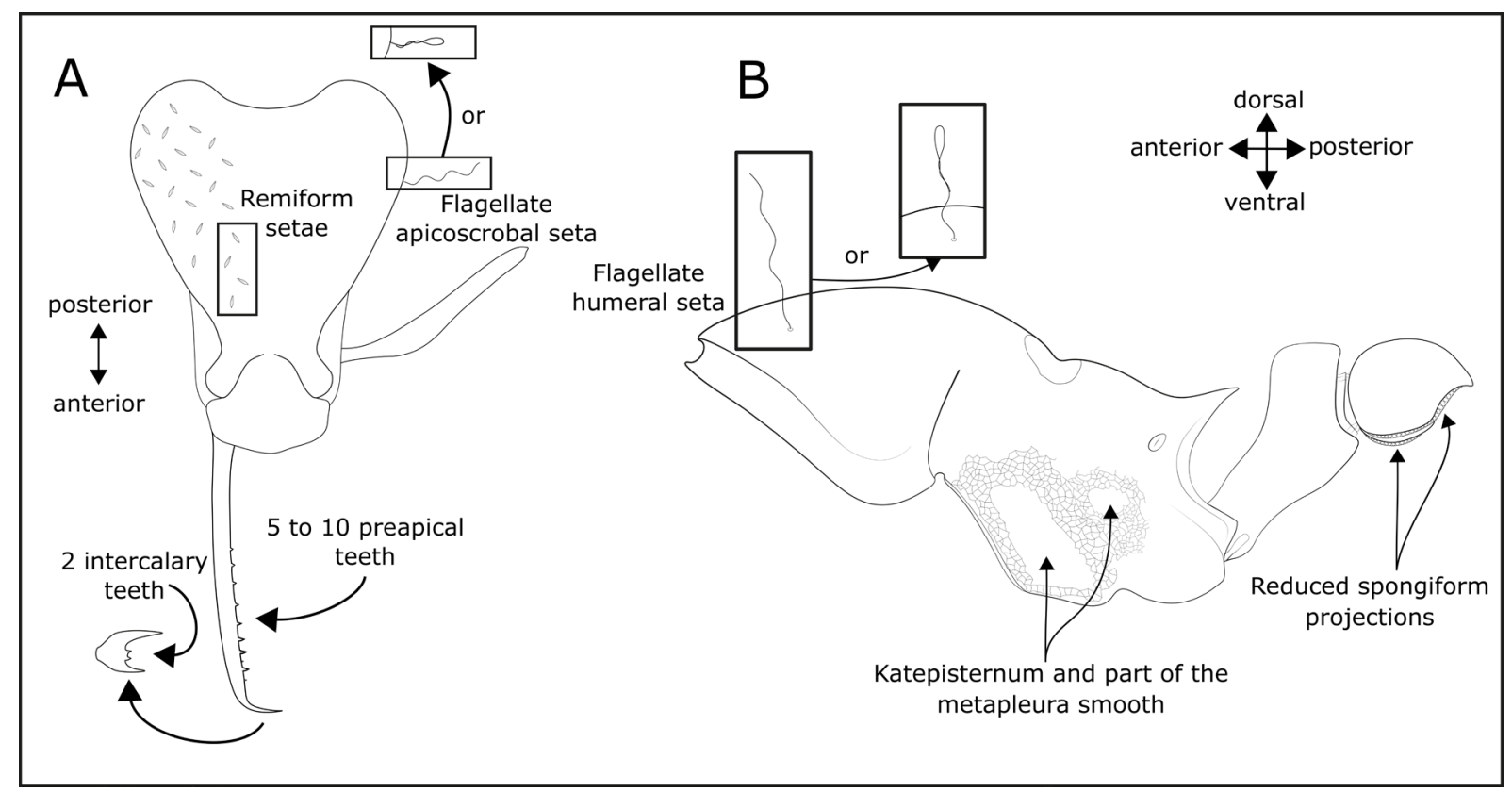

Fig. 4. Generalized schematics of Strumigenys denticulata Mayr, 1887, showing useful identification features. A. Head in dorsal view. B. Mesosoma, petiole, and postpetiole in lateral view. 
According to Bolton (2000), some specimens identified as $S$. denticulata have the katepisternum entirely reticulate-punctate, while all specimens observed in this study (cf. examined material) have a smooth patch in the katepisternum, including the lectotype. All specimens observed had the fourth abdominal tergite mostly smooth, only with the base of the sclerite with reticulate-punctate sculpture.

One of the paralectotypes (BMNH(E)1013551) is missing the postpetiole and gaster, rendering it impossible to evaluate morphological variability of those body regions in this particular individual.

Strumigenys eggersi Emery, 1890

Figs 5-6

Strumigenys eggersi Emery, 1890: 69.

Strumigenys (Pyramica) eggersi - Brown 1948: 110.

Pyramica eggersi - Bolton 1999: 1673.

Strumigenys eggersi - Baroni Urbani \& De Andrade 2007: 128.

\section{Diagnosis}

Strumigenys eggersi mostly resembles $S$. denticulata and can be distinguished from this species by the combination of shorter mandibles (ML 0.288 and MI 65.6 from the former opposed to the ML 0.355 and MI 84.9 from the latter), humeral setae filiform (Fig. 6B), presence of a pair of erect setae in the anteromedial area of the pronotum (Fig. 6B), and fourth abdominal tergite mostly sculptured.

\section{Type material}

Lectotype (designated herein) (label information) (Fig. 5)

BRAZIL - "Strumigenys eggersi St. Thomas Eggers" [handwritten]; "Typus" [printed]; "ANTWEB CASENT 0904936” [printed]; "Strumigenys eggersi Emery, 1890 LECTOTYPE” [printed]; MCSN.

Paralectotypes (label information)

BRAZIL - 2 workers; same label information as for lectotype; "Strumigenys eggersi Emery, 1890 PARALECTOTYPE" [printed]; MCSN • 1 worker; same label information as for lectotype; "Strumigenys eggersi Emery, 1890 PARALECTOTYPE" [printed]; "MZSP78535" [printed]; MZSP • 1 worker; "St. Thomas" [handwritten]; "G. Mayr" [printed]; "Type" [printed]; "Strumigenys eggersi Emery, 1890 PARALECTOTYPE" [printed]; "NHMW-HYM4953" [printed]; NHMW • 1 worker; same label information as for preceding; "NHMW-HYM4954" [printed]; NHMW • 1 worker; "S. Thomas" [handwritten]; "Strumigenys eggersi Em." [handwritten]; "Strumigenys Eggersi Emery S. Thomas" [handwritten]; "Type" [printed]; "GBIF-D/FoCol 2160 specimen + label data documented" [printed]; ZMHB.

\section{Additional material examined}

BRAZIL - Bahia • 5 workers; Ilhéus; 1447'36.62" S, 39²'46.97" W; [no date]; [no collector]; MZSP. - Espírito Santo • 1 worker; Reserva Biológica Córrego Grande; 18¹0'55.8" S, 3954'19.8" W; 51 m a.s.l.; 31 Jan. 2018-5 Feb. 2018; N. Safar, H. Cândido, and M. Cóser leg.; Winkler; CELC, UFVLABECOL-008214. - Mato Grosso • 1 worker; Canarana-Querência; $13^{\circ} 04^{\prime}$ S, 52 $2^{\circ} 23^{\prime}$ W; M. Bicalho and V. Ribeiro leg.; UFV-LABECOL-001788. - Minas Gerais - 1 worker; Viçosa; 13 Mar. 1998; S.M. Soares leg.; CELC, UFV-LABECOL-001805 • 1 worker; Araponga; Apr. 2011; D. Muscardi; CELC, UFV-LABECOL-001811 • 1 worker; Viçosa, Horto UFV; 2045'24.11" S, 42 52'26.43" W; $660 \mathrm{~m}$ a.s.1.; Mar. 2012; J. Chaul leg.; CELC, UFV-LABECOL-001790 • 1 queen; Viçosa; 2046'12.3" S, 4252'02.4" W; 29 Feb. 2016; S. Epifânio, R. Jesus and J. Chaul leg.; CELC, UFV-LABECOL-007490 - 1 worker; Monte Carmelo; 23-26 May 2016; J.M.M. Aguiar leg.; CELC, UFV-LABECOL-008354 • 
1 queen; Buritizeiro, Fazenda Porto; Feb. 2005; R.B.F. Campos leg.; CELC, UFV-LABECOL-001816 - 1 worker; Ipaba, Fazenda Macedônia; Jan. 2005; T. Marques leg.; CELC, UFV-LABECOL-001813. Santa Catarina - 1 queen; Araranguá, Restinga Morro dos Conventos; 7-23 Jan. 2008; D.C. Cardoso and M.P. Cristiano leg.; CELC, UFV-LABECOL-001815. - Pará • 1 worker; Paragominas; Jan.-Jul. 2011; R. Solar leg.; CELC, UFV-LABECOL-001778. - Paraná • 1 worker; Matinhos; 2549'26.94" S, 48 32'58.14" W; [no date]; [no collector]; MZSP. - Rio Grande do Sul • 2 workers; Morro Reuter; $29^{\circ} 32^{\prime} 18^{\prime \prime} \mathrm{S}, 51^{\circ} 4^{\prime} 53.86^{\prime \prime} \mathrm{W}$; [no date]; [no collector]; MZSP. - Rio de Janeiro • 1 worker; Santa Teresa; 22 ${ }^{\circ} 56^{\prime} 42.11^{\prime \prime}$ S, $43^{\circ} 12^{\prime} 39.70^{\prime \prime}$ W; [no date]; [no collector]; MZSP. - São Paulo • 1 worker; Ilha dos Búzios; 2347'56.89" S, 457'60.00" W; [no date]; [no collector]; MZSP.

\section{Lectotype measurements}

ABD4L 0.321; DPW 0.104; EL 0.043; HL 0.439; HT 0.25; HW 0.366; ML 0.288; PH 0.115; PL 0.197; PPL 0.098; PW 0.245; SL 0.221; WL 0.461; TL 1.872; CI 83.4; DPI 52.8; LPI 58.4; MI 65.6; OI 11.7; SI 60.4 .

\section{Paralectotype measurements}

ABD4L 0.304; DPW 0.102; EL 0.036; HL 0.415; HT 0.253; HW 0.343; ML 0.278; PH 0.107; PL 0.202; PPL 0.087; PW 0.241; SL 0.230; WL 0.443; TL 1.729; CI 82.7; DPI 50.5; LPI 53.0; MI 67.0; OI 10.5; SI $67.1(\mathrm{n}=1$; ZMHB GBIF-D/FoCol 2160).

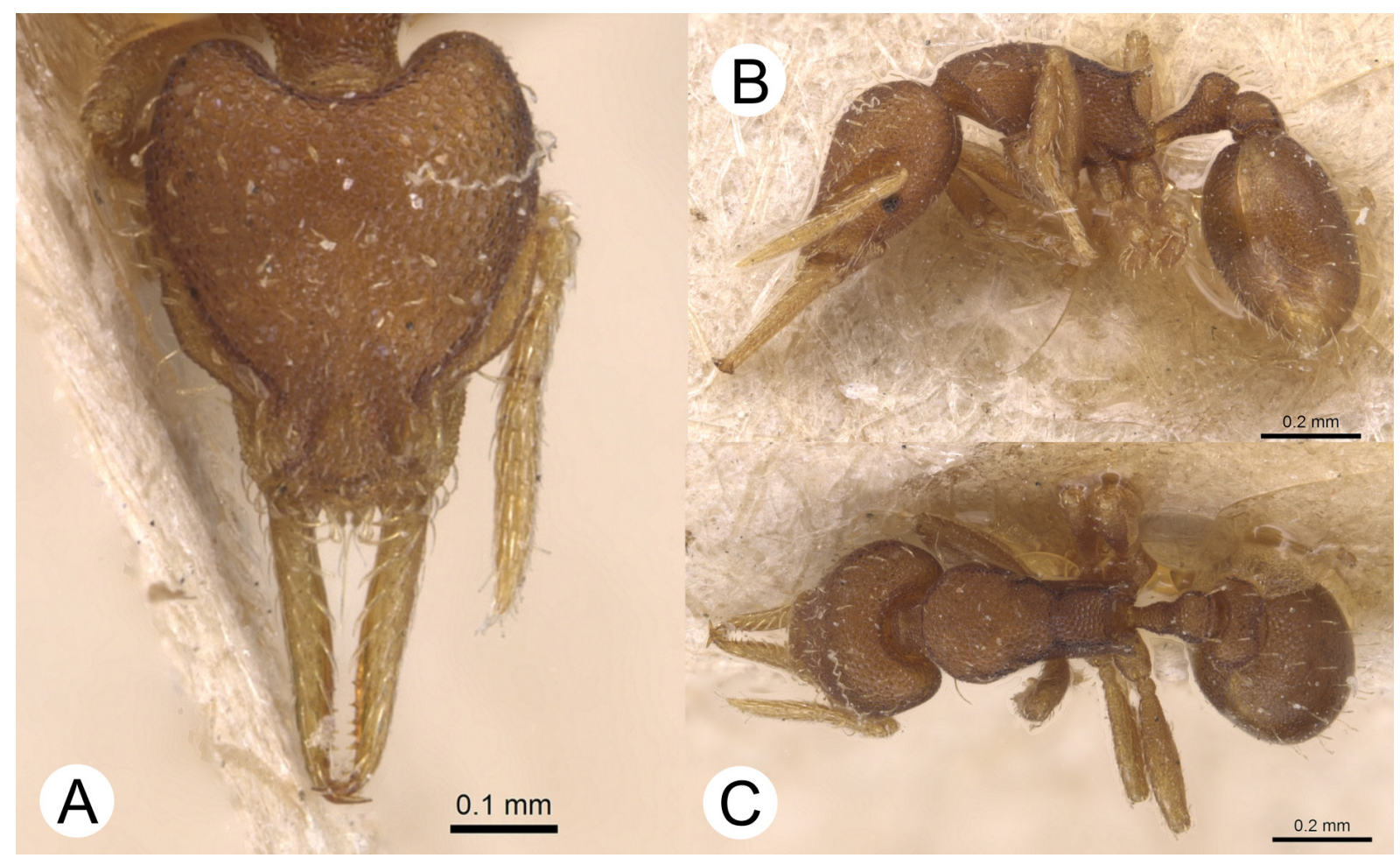

Fig. 5. Lectotype of Strumigenys eggersi Emery, 1890 (CC-BY, CASENT0904936, Will Ericson, from www.antweb.org). A. Head, mandibles and antennae, in dorsal view. B. Full body, in lateral view. C. Full body, in dorsal view. 


\section{Non-type measurements}

ABD4L 0.320-0.410; DPW 0.085-0.115; EL 0.040-0.050; HL 0.420-0.470; HT 0.240-0.270; HW 0.340-0.390; ML 0.250-0.280; PH 0.110-0.130; PL 0.190-0.210; PPL 0.080-0.100; PW 0.2200.255 ; SL $0.220-0.250$; WL $0.420-0.490$; TL 1.690-1.955; CI 81.0-86.0; DPI 44.7-55.3; LPI 55.061.9; MI 58.1-65.9; OI 10.8-14.1; SI 62.0-66.7 $(\mathrm{n}=6)$.

\section{Description}

SCULPTURE. Head entirely reticulate-punctate, including antennal scrobe. Mesosoma entirely reticulatepunctate, except for katepisternum which is smooth (Fig. 6B). Fourth abdominal tergite reticulatepunctate almost entirely. Length of basigastral costulae, in dorsal view, less than half the length of postpetiole.

SETAE. Cephalic ground-setae remiform (Fig, 6A). Two pairs of remiform erect setae on cephalic dorsum; both pairs located in the posterior third of cephalic dorsum, one pair nearer to occipital margin than the other. Apicoscrobal setae flagellate (Fig. 6A). Anterior margin of scape with one or more remiform setae curved towards antennal insertion. Humeral setae filiform (Fig. 6B). Pair of erect setae located in the antero-medial area of pronotum filiform (Fig. 6B). Setae on petiole, postpetiole and fourth abdominal tergite remiform to slightly clavate.

HEAD. Masticatory margin of mandible with six preapical denticles (Fig. 6A). Apex of mandible with two minute intercalary denticles (Fig. 6A). Anterior clypeal margin, in dorsal view, convex medially. Eye, in lateral view, with three ommatidia in the longest row. Eye located in the anterior half of head. In dorsal view, scape cylindrical. Third flagellomere smaller than fourth flagellomere; length of former almost a third of length of latter.

Mesosoma. Humerus with a small angular projection. Dorsum of mesonotum, in lateral view, convex, confluent with dorsum of pronotum. Metanotal groove relatively well impressed. Propodeal spine

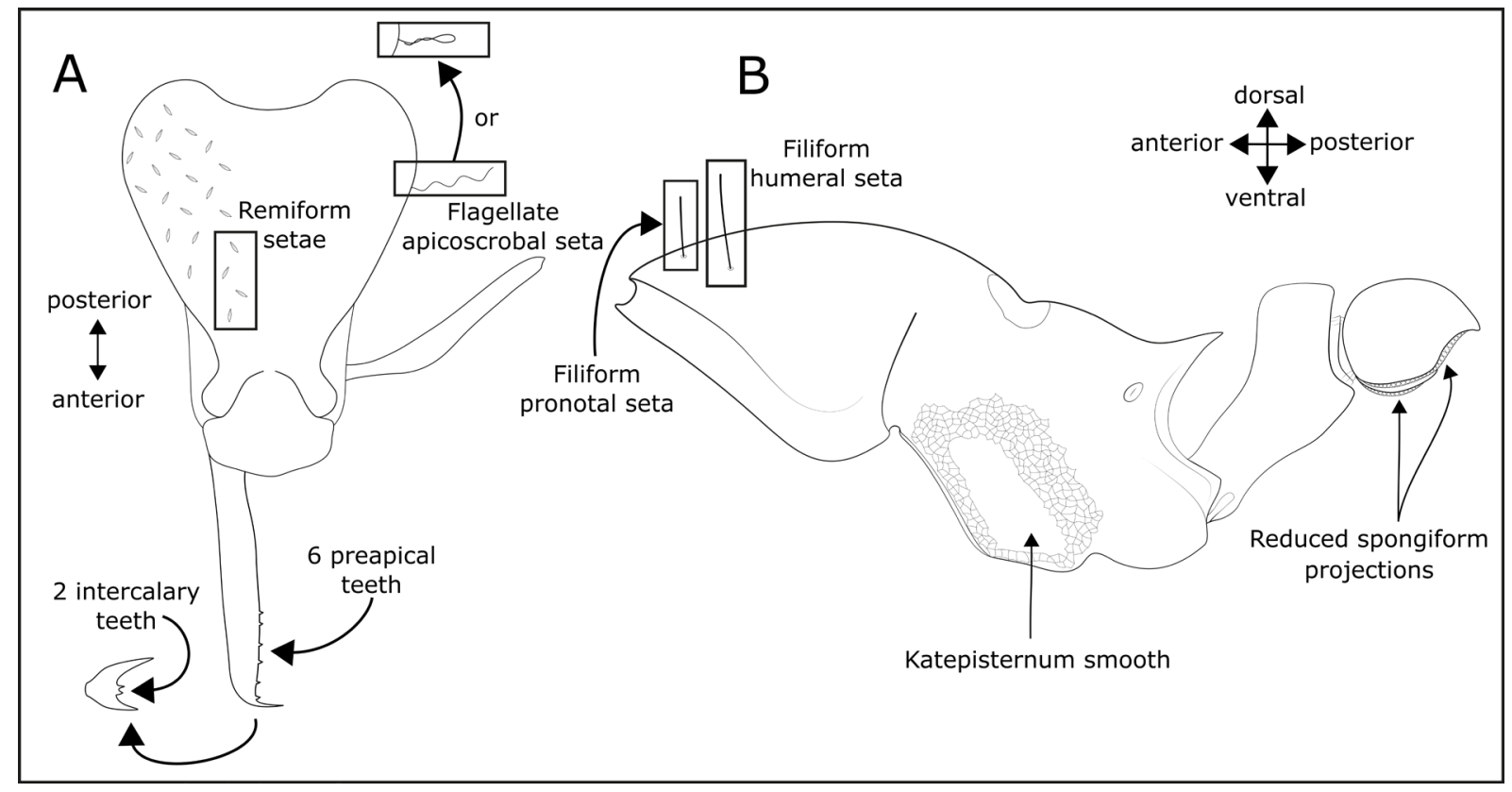

Fig. 6. Generalized schematics of Strumigenys eggersi Emery, 1890, showing useful identification features. A. Head in dorsal view. B. Mesosoma, petiole, and postpetiole in lateral view. 
relatively long and triangular, somewhat translucent, and linked to propodeal lobe by a narrow lamella that extends throughout propodeal declivity. Femoral bulla small, ovate and located distally on the dorsal margin of sclerite.

Metasoma. Petiolar node, in dorsal view, wider than long; in lateral view, anterior margin longer than dorsal margin. Anterior margin of postpetiole, in dorsal view, medially concave. Lateral and ventral spongiform processes of petiole absent. Ventral spongiform lobe of postpetiole small (Fig. 6B). Lateral spongiform lobe of postpetiole minute, almost vestigial (Fig. 6B). Ventral basigastral spongiform pad reduced to curved (U-shaped in anterior view) carina.

\section{Comments}

Bolton (2000) considered S. eggersi as a member of the gundlachi complex (i.e., a cluster of species under the gundlachi species group), along with Strumigenys connectens Kempf, 1958, S. decipula (Bolton, 2000), S. denticulata Mayr, 1887, S. enopla (Bolton, 2000), S. gemella Kempf, 1975, S. gundlachi (Roger, 1862), S. jamaicensis Brown, 1959, S. laevipleura Kempf, 1858, S. lalassa (Bolton, 2000), S. nubila Lattke \& Goitía, 1997, S. subedentata Mayr, 1887, S. trieces Brown, 1960, S. vartana (Bolton, 2000), and S. xenognatha Kempf, 1958.

This species is widespread in the Neotropics, with its northernmost range in Florida, USA (Wetterer 2018) and southernmost range in Santa Fé, Argentina (Vittar \& Cuezzo 2008). According to Wetterer (2018), this species can be commonly found in urban areas when occurring outside its original range, which was, according to Brown (1960), "probably south Brazil and Bolivia, though a lack of collections from central and northern Brazil prevents us from knowing how far north this species extends". Since Brown's (1960) work, the number of records of S. eggersi in the Neotropical region has greatly increased, especially due to recent sampling efforts conducted in ecosystems both within and adjacent to the Amazon basin. Nonetheless, there still remains a large record gap for the species in the center of the Amazon biome. Although the revision of the species was not the aim of the present work, it is important to consider that the continuous reduction of this 'distribution gap' is fundamental when addressing the specific boundaries for $S$. eggersi.

Among the specimens examined, dentition patterns varied greatly, both in size and number. In the lectotype, there are total of seven preapical teeth restricted to the distal third of the inner margin of the mandible, while in some other specimens observed there are five or six preapical teeth. Bolton (2000) mentioned that specimens belonging to $S$. eggersi can have four to eight teeth in the inner margin of the mandible, indicating that teeth variation is expected in this species. However, Longino (2006) provided an important account on the usefulness of teeth variation in demarcating different species of Strumigenys belonging to the gundlachi group, indicating that dental variation (number and relative size of teeth) should be carefully considered when discriminating potential new species in this group.

Strumigenys subedentata Mayr, 1887

Figs 7-8

Strumigenys subedentata Mayr, 1887: 575.

Strumigenys tristani Menozzi 1931: 273, fig. 8 (synonymyzed by Brown 1960).

Strumigenys (Strumigenys) clavata Weber 1934: 32, fig. 8 (synonymyzed by Brown 1960).

Pyramica kiranae Makhan 2007: 4 figs 7-8 (synonymyzed by Bolton et al. 2008).

Pyramica subedentata - Bolton 1999: 1673.

Strumigenys subedentata - Baroni Urbani \& De Andrade 2007: 128. 


\section{Diagnosis}

Strumigenys subedentata can be distinguished from other Neotropical species by the combination of five pairs of remiform setae on promesonotum (Fig. 8B), anterior area of fourth abdominal tergite reticulatepunctate (Fig. 8C), and anterior area of fourth abdominal sternite reticulate-punctate.

\section{Type material}

Lectotype (designated herein) (label information) (Fig. 7)

BRAZIL - "St. Catharina Coll. G. Mayr" [printed]; "Brit. Mus. 1922-501" [printed]; "edentata" [handwritten] "G. Mayr, Type" [printed]; "BMNH(E) 1013552" [printed]; "ANTWEB CASENT 0900181" [printed]. "Syntype" [printed]. "Strumigenys subedentata Mayr, 1887 LECTOTYPE" [printed]; NHMUK.

Paralectotypes (label information)

BRAZIL • 1 worker; "St. Catharina Coll. G. Mayr" [printed; Syntype [printed]; "Strumigenys subedentata Mayr, 1887" PARALECTOTYPE [printed]; NHMW-HYM4957 • 1 worker; same label information as for preceding; "Strumigenys subedentata Mayr, 1887 PARALECTOTYPE" [printed]; NHMW-HYM4958 • 1 worker; same label information as for preceding; NHMW-HYM4961 • 1 worker; same label information as for preceding; NHMW-HYM4962 1 worker; same label information as for preceding; NHMW-HYM4963 • 1 worker; same label information as for preceding; NHMW-HYM4964 - 1 worker; same label information as for preceding; NHMW-HYM4965 - 1 worker; "St. Cath. Hetschko" [printed]; "Syntype" [printed]; "Strumigenys subedentata Mayr, 1887" PARALECTOTYPE [printed]; NHMW-HYM4959 • 1 worker; same label information as for preceding; NHMW-HYM4960 - 1 worker; "St. Catharina Coll. G. Mayr" [printed]; "126 Hetschko 1/984" [handwritten]; "edentata" [handwritten] "G. Mayr, Type" [printed]; "Pyramica subedentata" [handwritten] "det. B. Bolton 1999" [printed] "ANTWEB CASENT 0915703" [printed]; "Syntype" [printed]. "Strumigenys subedentata Mayr, 1887 PARALECTOTYPE" [printed]. NHMW-HYM4956 • 1 worker; same label information as for lectotype; "Strumigenys subedentata Mayr, 1887 PARALECTOTYPE” [printed]; MCZT_28507.

\section{Additional material examined}

BRAZIL - Amazonas • 1 worker; Manaus, Colosso Camp; 12-21 Aug. 2016; B. Boudinot, L. Fernandes and J. Chaul leg.; CELC, ANTWEB1038944. - Bahia • 1 worker; Itacaré; 14²17'38.0" S, 38 59'08.6" W; 23 Aug. 2015; J. Chaul leg.; CELC, UFV-LABECOL-001969. - Espírito Santo • 1 worker; Santa Teresa, Estação Biológica Santa Lúcia; 1957'58.4" S, 40³2'21.2" W; 30 Jan. 2015; T. Vargas leg.; CELC, UFV-LABECOL • 1 worker, 1 queen; near Reserva Biológica Córrego Grande; 18 14'11.3" S, 3949'12.1" W; 21 Apr.-10 May 2017; N. Safar, C. Aquila and C. Guimarães leg.; Winkler; CELC, UFV-LABECOL-008544. - Minas Gerais • 1 worker; Viçosa, Floresta Secundária; Feb. 1994; Sperber, Louzada and Lopes leg.; CELC, UFV-LABECOL-001792 - 1 worker; same collection data as for preceding; CELC, UFV-LABECOL-001780 • 1 worker; Viçosa; 13 Jan. 1998; S.M. Soares leg.; CELC, UFV-LABECOL-001771 • 1 worker; Viçosa, Mata da Biologia; 2045'26.67" S, 4251'39.07" W; 706 m a.s.l.; Feb. 2013; J. Chaul leg.; CELC, UFV-LABECOL-001797 • 1 worker; Viçosa, Mata da Biologia; 2045'30.44" S, 42 51'49.65" W; 731 m a.s.1.; 5 May 2013; J. Chaul and N. Safar leg.; epigaeic Winkler; CELC, UFV-LABECOL-001802 • 1 worker, 1 queen; Viçosa, Mata do Paraíso; 20 48'20.5" S, 42 51'12.4" W; 781 m a.s.1.; 2013; J. Chaul and R. Jesus leg.; Winkler; CELC, UFV-LABECOL-008225 - 1 worker; Viçosa, Mata do Seu Nico; 2047'43.8" S, 4250'51.8" W; 750 m a.s.1.; 8 May 2013; J. Chaul and R. Jesus leg.; Winkler; CELC, UFV-LABECOL-008225 • 2 workers; Viçosa, Mata da Biologia; 2045'30" S, 42 51'50.3" W; 17 Aug. 2014; J. Chaul leg.; Winkler; CELC, UFV-LABECOL-001765 - 3 workers; Viçosa; 2046'07" S, 42 52'02" W; 17 Jul. 2015; J. Chaul, R. Jesus, F. Rezende and A. Orsetti leg.; Winkler; CELC, UFV-LABECOL-008593 • 1 worker; Santana de Patos, Fazenda Lagoa Formosa; 1851'45" S, 46³4'17" W; Feb. 2014; L-N- Paolucci leg.; CELC, UFV-LABECOL-001779 
- 1 worker; São Tiago; 2057'09.69" S, 44²6’32.09" W; Feb. 2012; M. Padilha leg.; CELC, UFVLABECOL-010751 • 1 worker; Ipaba, Reserva Particular do Patrimônio Natural Fazenda Macedônia, CENIBRA; Nov. 2005; T. Marques leg.; CELC, UFV-LABECOL-001798 • 1 worker; Conceição do Mato Dentro, Serra da Serpentina; $19.03394^{\circ}$ S, $43.33687^{\circ}$ W; $1-7$ Sep. 2010; R.R. Silva leg.; Winkler; CELC, UFV-LABECOL-010461 - Pará • 1 worker; Paragominas; Jan.-Jul. 2011; R. Solar leg.; CELC, UFV-LABECOL-001804 • 1 worker, 1 queen; Primavera; $01^{\circ} 00^{\prime} 36^{\prime \prime}$ S, 47 $07^{\circ} 04^{\prime \prime}$ W; 5-6 Nov. 2018; L.P. Prado and K.L.S. Sampaio leg.; Winkler; CELC, UFV-LABECOL-010487. - Paraná • 4 workers; Floresta Estadual do Palmito, km 28; 2559'10.62" S, 4855'68.09" W; 20 m a.s.1.; 28 Apr. 2016; J. Lattke leg.; DZUP. - Rio de Janeiro - 1 worker; Santa Maria Madalena, Horto Florestal; 21 ${ }^{\circ} 57^{\prime} 01.5^{\prime \prime}$ S,

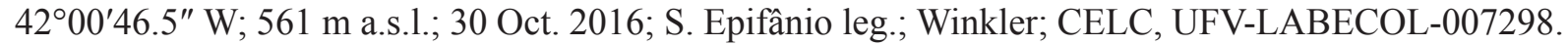

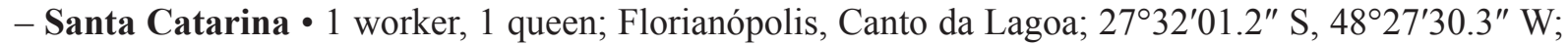
15 Feb. 2016; J. Chaul leg.; CELC, UFV-LABECOL-002490 • 1 worker; same collection data as for preceding; CELC, UFV-LABECOL-008232 - 1 worker; same collection data as for preceding; CELC, UFV-LABECOL-008231 • 1 worker; Florianópolis, Lagoinha do Leste; $27^{\circ} 46^{\prime} 31.0^{\prime \prime}$ S, 48 $29^{\prime} 06.0^{\prime \prime} \mathrm{W}$; 18 Feb. 2016; J. Chaul leg.; CELC, UFV-LABECOL-008222 • 1 queen; same collection data as for preceding; CELC, UFV-LABECOL-008221.

PERU - Madre de Dios • 1 worker; Puerto Maldonado, Reserva Nacional Tambopata; $12^{\circ} 51^{\prime} 21^{\prime \prime}$ S, 69²1'43" W; 210 m a.s.1.; 19-31 Jul. 2012; R. Feitosa leg.; CELC, UFV-LABECOL-001789.

\section{Lectotype measurements}

ABD4L 0.455; DPW 0.101; EL 0.054; HL 0.534; HT 0.324; HW 0.475; ML 0.306; PH 0.138; PL 0.283; PPL 0.141; PW 0.291; SL 0.267; WL 0.545; TL 2.264; CI 88.9; DPI 35.7; LPI 48.7; MI 57.3; OI 11.3; SI 56.2 .

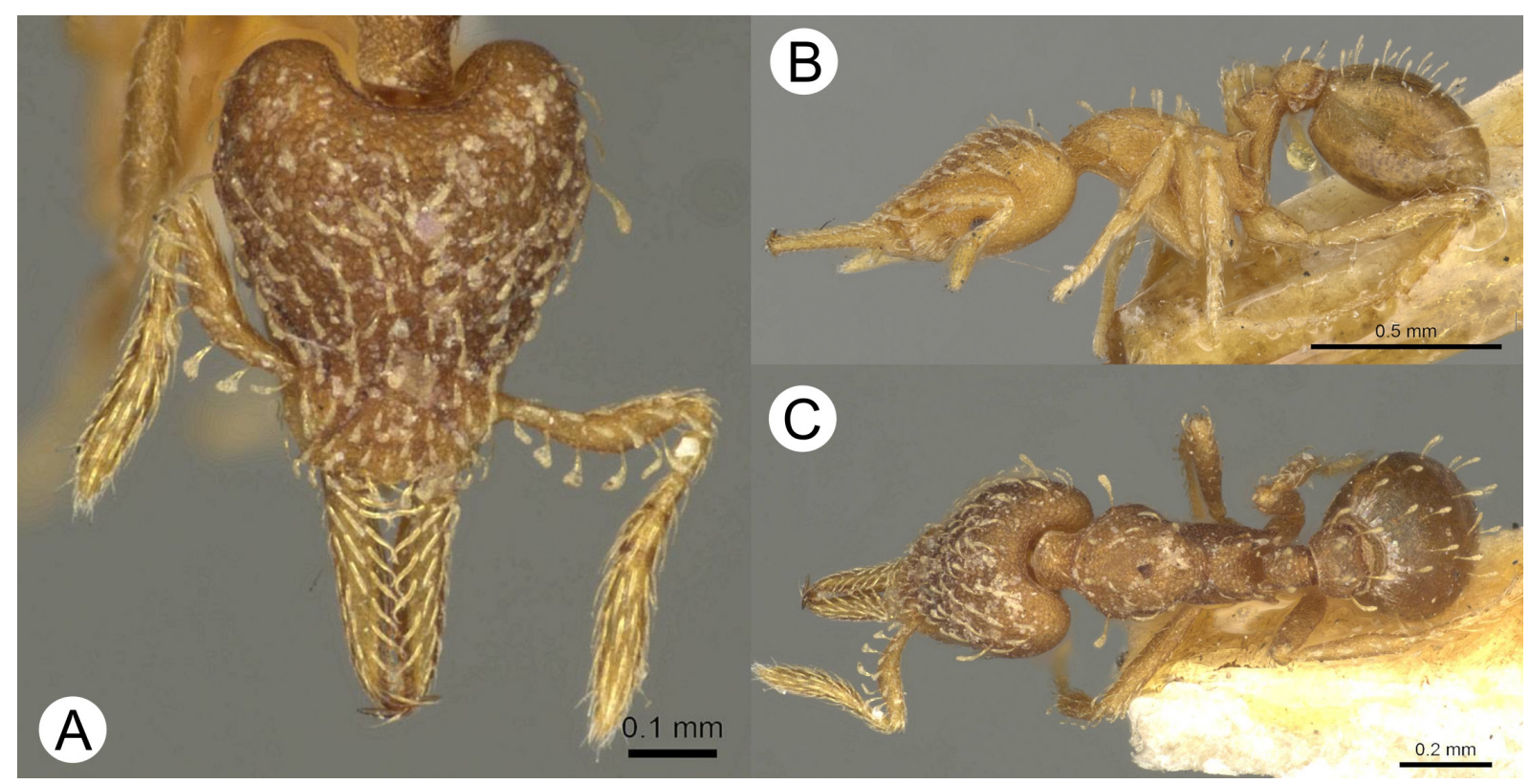

Fig. 7. Lectotype of Strumigenys subedentata Mayr, 1887 (CC-BY, CASENT0915703, Harald Bruckner, from www.antweb.org). A. Head, mandibles and antennae, in dorsal view. B. Full body, in lateral view. C. Full body, in dorsal view. 


\section{Paralectotype measurements}

ABD4L 0.424; DPW 0.104; EL 0.054; HL 0.500; HT 0.300; HW 0.434; ML 0.282; PH 0.119; PL 0.243; PPL 0.146; PW 0.251; SL 0.242; WL 0.481; TL 2.076; CI 86.8; DPI 42.8; LPI 49.0; MI 56.4; OI 12.4; SI $55.8(\mathrm{n}=1$; CASENT 0915703).

\section{Non-type measurements}

ABD4L 0.410-0.520; DPW 0.105-0.290; EL 0.055-0.075; HL 0.490-0.575; HT 0.300-0.350; HW 0.430-0.520; ML 0.270-0.310; PH 0.130-0.160; PL 0.240-0.290; PPL 0.100-0.135; PW 0.1850.310; SL 0.260-0.300; WL 0.510-0.610; TL 2.050-2.440; CI 85.3-90.4; DPI 40.4-103.6; LPI 50.058.5; MI 52.9-60.8; OI 12.8-15.1; SI 55.8-63.6 $(\mathrm{n}=10)$.

\section{Description}

SCULPTURE. Head entirely reticulate-punctate, including antennal scrobe. Mesosoma entirely reticulatepunctate (see Comments). Fourth abdominal tergite reticulate-punctate near base (Fig. 8C). Length of basigastral costulae, in dorsal view, almost half length of postpetiole.

SETAE. Cephalic ground-setae remiform (Fig. 8A). Two pairs of remiform erect setae on cephalic dorsum; both pairs located on posterior third of cephalic dorsum, one pair nearer to occipital margin. Apicoscrobal setae remiform (Fig. 8A). Anterior margin of scape with one or more remiform setae curved towards antennal insertion. Humeral setae remiform (Fig. 8B). Four pairs of erect remiform setae (excluding humeral pair) on promesonotum (Fig. 8B). Setae on petiole, postpetiole and fourth abdominal tergite remiform.

HeAD. Masticatory margin of mandible with five preapical denticles (Fig. 8A; see Comments). Apex of mandible with two minute intercalary denticles (Fig. 8A). Anterior clypeal margin, in dorsal view, angular medially. Eye, in lateral view, with five to seven ommatidia along longest row. Eye located on

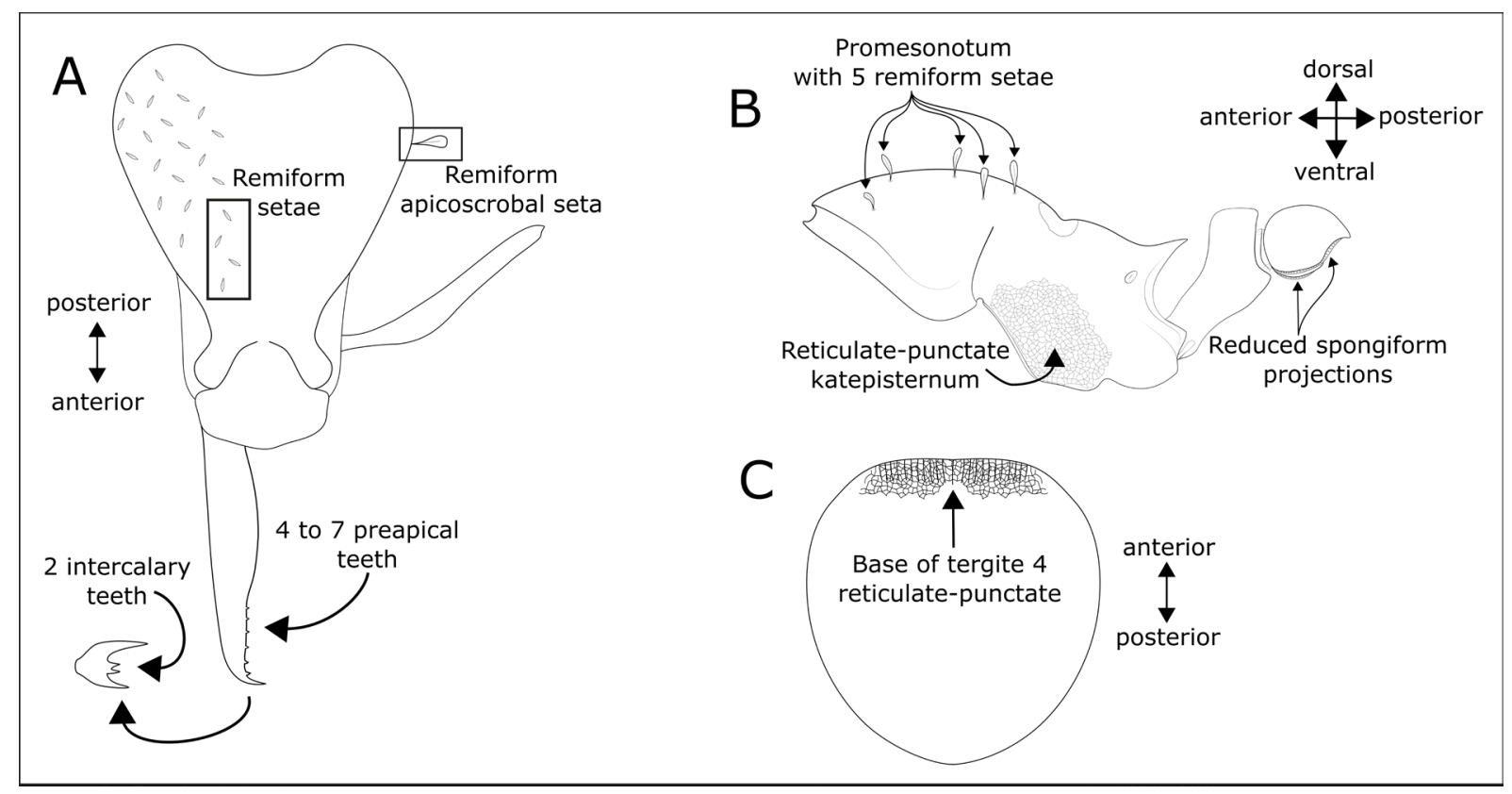

Fig. 8. Generalized schematics of Strumigenys subedentata Mayr, 1887, showing useful identification features. A. Head in dorsal view. B. Mesosoma, petiole, and postpetiole, in lateral view. C. Fourth abdominal tergite in dorsal view. 
anterior half of head. In dorsal view, scape dorsoventrally flattened, expanded throughout its length. Third flagellomere smaller than fourth flagellomere; length of former almost half length of latter.

Mesosoma. Humerus with small angular projection. Dorsum of mesonotum, in lateral view, convex, confluent with dorsum of pronotum. Metanotal groove relatively well impressed. Propodeal spine long and triangular, translucent, and linked to propodeal lobe by narrow lamella that extends throughout propodeal declivity. Femoral bulla small, ovate and located distally on dorsal margin of sclerite.

Metasoma. Petiolar node, in dorsal view, as long as wide; in lateral view, anterior margin almost as long as dorsal margin. Anterior margin of postpetiole, in dorsal view, slightly concave, almost straight. Lateral and ventral spongiform processes of petiole absent. Ventral spongiform lobe of postpetiole small. Lateral spongiform lobe of postpetiole small. Ventral basigastral spongiform pad reduced to curved (U-shaped in anterior view) carina.

\section{Comments}

Bolton (2000) considered S. subedentata as a member of the gundlachi complex (see Comments in S. denticulata). The lectotype and the additional examined specimens did not show major morphological variation. Most specimens have an entirely reticulate-punctate katepisternum; however, some of them have a small but distinct smooth patch on the ventral-most area of the katepisternum. Although it is not possible to clearly determine if the katepisternum of the lectotype has a smooth patch based solely on images, direct observation of the physical specimen showed that this anatomical region is entirely sculptured (G. Broad pers. comm.).

In the lectotype specimen both mandibles possess five preapical teeth each (G. Broad pers. comm.), while in almost every non-type specimen observed in this study this number varied, in a symmetrical manner, from four to seven in each mandible. However, in a few specimens, we observed asymmetric variation in dentition count, which, despite not being a prevalent condition, it is a noteworthy variation.

Despite the wide range of occurrence of the species, the observed morphological traits did not presented a high variability degree, agreeing with Bolton's (2000) own observations. Nonetheless, examination of specimens sampled in other ecosystems within the Neotropical region will provide a clearer understanding of morphological variation along the distribution range of $S$. subedentata, allowing for a better delimitation of the species' boundaries in future revisionary endeavors.

\section{Discussion}

With the overall increase in representation of these four Strumigenys species in myrmecological collections, the morphological variability described by Bolton (2000) is becoming frequently documented, urging for a reassessment of the limits for these species. Adjusting and normalizing nomenclatural acts, along with their associated criteria, is necessary to provide an objective assessment of the defining features of any given taxon and for providing support for validation of taxonomic identities. Future revisionary efforts should consider expanding the specimen distribution coverage as to better explore morphological variability in a broader geographical perspective, especially considering how several locations that were considered to be knowledge gaps are now better represented in collections. Nonetheless, with the increased deforestation rates occurring in localities that hold an important part of biological diversity, especially in the Brazilian Amazon Forest, it is possible that much of this knowledge is at risk of disappearing.

With the lectotype designations for S. crassicornis, S. denticulata, S. eggersi, and S. subedentata, we take a step back but two steps forward in establishing clearer boundaries for some of the most common Strumigenys species in the Neotropical region. 


\section{Acknowledgements}

We are deeply grateful to Bonnie Blaimer, who provided vital information on a type specimen of Strumigenys eggersi deposited in the ZMHB. Also, Gavin Broad provided us with important information about some morphological traits from Strumigenys subedentata lectotype deposited in the NHMUK. We are equally grateful to the support of all managers and curators of the contacted collections: Bonnie Blaimer, Carlos Roberto Ferreira Brandão, Crystal Maier, Dominique Zimmermann, Maria Tavano, Mônica Antunes Ulysséa, Stephanie Krause, and Suzanne Ryder. We also appreciate the help of Itanna Oliveira Fernandes and Lívia Pires do Prado for sending some non-type specimens used in this study. We are also indebted to two anonymous reviewers who suggested changes that greatly improved the manuscript. TSRS did not receive any grant during the elaboration of this work. JCMC was funded by the Coordination for the Improvement of Higher Education Personnel [CAPES grant 88882.437415/201901]. RMF was funded by the Brazilian Council of Research and Scientific Development [CNPq grant 301495/2019-0]. This research was carried out during a period of systematic down-sizing of democratic and scientific institutions in Brazil, by the government of Jair Messias Bolsonaro, which occurred simultaneously with a notorious upsurge of environmental disasters and illegal activities during the office of the former Minister of the Environment, Ricardo de Aquino Salles.

\section{References}

Baroni Urbani C. \& De Andrade M.L. 2007. The ant tribe Dacetini: limits and constituent genera, with descriptions of new species (Hymenoptera, Formicidae). Annali del Museo Civico di Storia Naturale "Giacomo Doria" 99: 1-191.

Bolton B. 1998. Monophyly of the dacetonine tribe-group and its component tribes (Hymenoptera: Formicidae). Bulletin of the Natural History Museum. Entomology Series 67 (1): 65-78. Available from https://www.biodiversitylibrary.org/page/40885398 [accessed 21 Feb. 2022].

Bolton B. 1999. Ant genera of the tribe Dacetonini (Hymenoptera: Formicidae). Journal of Natural History 33: 1639-1689. https://doi.org/10.1080/002229399299798

Bolton B. 2000. The ant tribe Dacetini. Memoirs of the American Entomological Institute 65: 1-1028.

Bolton B. 2021. An online catalog of the ants of the world. Available from https://antcat.org. [accessed 3 Feb. 2021].

Bolton B., Sosa-Calvo J., Fernández F. \& Lattke J.E. 2008. New synonyms in neotropical myrmicine ants. Zootaxa 1732 (1): 61-64. https://doi.org/10.11646/zootaxa.1732.1.5

Booher D.B. \& Hoenle P.O. 2021. A new species group of Strumigenys (Hymenoptera, Formicidae) from Ecuador, with a description of its mandible morphology. ZooKeys 1036: 1-19.

https://doi.org/10.3897/zookeys.1036.62034

Booher D.B., Prebus M.M. \& Lubertazzi D. 2019. A taxonomic revision of the Strumigenys nitens and simulans groups (Hymenoptera: Formicidae), two Caribbean radiations of leaf litter ants. Zootaxa 4656 (2): 335-358. https://doi.org/10.11646/zootaxa.4656.2.7

Booher D.B., Gibson J.C., Liu C., Longino J.T., Fisher B.L., Janda M., Narula N., Toulkeridou E., Mikheyev A.S., Suarez A.V. \& Economo E.P. 2021. Functional innovation promotes diversification of form in the evolution of an ultrafast trap-jaw mechanism in ants. PLoS Biology 19 (3): e3001031. https://doi.org/10.1371/journal.pbio.3001031

Brassard F., Leong C.M., Chan H.H. \& Guénard B. 2020. A new subterranean species and an updated checklist of Strumigenys (Hymenoptera, Formicidae) from Macao SAR, China, with a key to species of the Greater Bay Area. ZooKeys 970: 63-116. https://doi.org/10.3897/zookeys.970.54958 
Brown W.L. Jr. 1948. A preliminary generic revision of the higher Dacetini (Hymenoptera: Formicidae). Transactions of the American Entomological Society 74: 101-129.

Brown W.L. Jr. 1959a. A revision of the dacetine ant genus Neostruma. Breviora 107: 1-13.

Brown W.L. Jr. 1959b. Some new species of dacetine ants. Breviora 108: 1-11.

Brown W.L. Jr. 1960. The neotropical species of the ant genus Strumigenys Fr. Smith: group of gundlachi (Roger). Psyche 66: 37-52. https://doi.org/10.1155/1959/80153

Brown W.L. Jr. 1961. The neotropical species of the ant genus Strumigenys Fr. Smith: miscellaneous concluding studies. Psyche 68: 58-69. https://doi.org/10.1155/1961/29696

Catapano T. 2019. TaxPub: an extension of the NLM/NCBI journal publishing DTD for taxonomic descriptions. Journal Article Tag Suite Conference (JATS-Con), Bethesda (MD), USA.

https://doi.org/10.5281/zenodo.3484285

Emery C. 1890. Studii sulle formiche della fauna neotropica. Bullettino della Società Entomologica Italiana 22: 38-80.

Ladino N. \& Feitosa R.M. 2020. Taxonomic revision of the genus Prionopelta Mayr, 1866 (Formicidae: Amblyoponinae) for the Neotropical region. Zootaxa 4821 (2): 201-249.

https://doi.org/10.11646/zootaxa.4821.2.1

Lattke J.E., Silva T.S.R. \& Delsinne T. 2018. Taxonomy and natural history of Strumigenys thaxteri Wheeler and Strumigenys reticeps (Kempf) (Hymenoptera: Formicidae). Zootaxa 4438 (1): 137-147. https://doi.org/10.11646/zootaxa.4438.1.6

Longino J.T. 2006. New species and nomenclatural changes for the Costa Rican ant fauna (Hymenoptera: Formicidae). Myrmecologische Nachrichten 8: 131-143.

Mayr G. 1887. Südamerikanische Formiciden. Verhandlungen der Kaiserlich-Königlichen ZoologischBotanischen Gesellschaft in Wien 37: 511-632. Available from

https://www.biodiversitylibrary.org/page/13988358 [accessed 8 Jul. 2021].

Oliveira A.M. \& Feitosa R.M. 2019. Taxonomic revision of the genus Probolomyrmex Mayr, 1901 (Hymenoptera: Formicidae: Proceratiinae) for the Neotropical Region. Zootaxa 4614 (1): 61-94. https://doi.org/10.11646/zootaxa.4614.1.3

Rasband W.S. 2018. ImageJ. U.S. National Institutes of Health, Bethesda, Md, USA. Available from https://imagej.nih.gov/ij [accessed 8 Jul. 2021].

Schulz S. \& Jansen L. 2013. Formal ontologies in biomedical knowledge representation. Yearbook of Medical Informatics 8 (1): 132-146. https://doi.org/10.1055/s-0038-1638845

Silva T.S.R. \& Feitosa R.M. 2019. Using controlled vocabularies in anatomical terminology: a case study with Strumigenys (Hymenoptera: Formicidae). Arthropod Structure and Development 52: 100877. https://doi.org/10.1016/j.asd.2019.100877

Tang K.L., Pierce M.P. \& Guénard B. 2019. Review of the genus Strumigenys (Hymenoptera, Formicidae, Myrmicinae) in Hong Kong with the description of three new species and the addition of five native and four introduced species records. ZooKeys 831: 1-48. https://doi.org/10.3897/zookeys.831.31515

Vittar F. \& Cuezzo F. 2008. Hormigas (Hymenoptera: Formicidae) de la provincia de Santa Fe, Argentina. Revista de la Sociedad Entomológica Argentina 67 (1-2): 175-178.

Ward P.S. 2000. Broad-scale patterns of diversity in leaf litter ant communities. In: Agosti D., Majer J.D., Alonso L.E. \& Schultz T.R. (eds) Ants. Standard Methods for Measuring and Monitoring Biodiversity: 99-121. Smithsonian Institution Press, Washington. 
Wetterer J.K. 2018. Geographic distributions of Strumigenys gundlachi and Strumigenys eggersi (Hymenoptera, Formicidae). Transactions of the American Entomological Society 144 (1): 131-141. https://doi.org/10.3157/061.144.0101

Manuscript received: 12 July 2021

Manuscript accepted: 10 December 2021

Published on: 3 March 2022

Topic editor: Tony Robillard

Section editor: Gavin Broad

Desk editor: Pepe Fernández

Printed versions of all papers are also deposited in the libraries of the institutes that are members of the EJT consortium: Muséum national d'histoire naturelle, Paris, France; Meise Botanic Garden, Belgium; Royal Museum for Central Africa, Tervuren, Belgium; Royal Belgian Institute of Natural Sciences, Brussels, Belgium; Natural History Museum of Denmark, Copenhagen, Denmark; Naturalis Biodiversity Center, Leiden, the Netherlands; Museo Nacional de Ciencias Naturales-CSIC, Madrid, Spain; Real Jardín Botánico de Madrid CSIC, Spain; Zoological Research Museum Alexander Koenig, Bonn, Germany; National Museum, Prague, Czech Republic. 